SELÇUK ÜNIVERSITESI

HUKUK FAKÜLTESI DERGISII

Selçuk Law Review

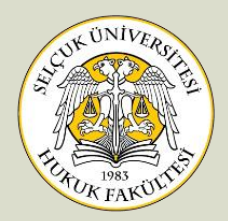

Araştırma Makalesi

Research Article

Gönderim | Received: 29.03.2021

Kabul | Accepted: 09.06.2021

doi) $10.15337 /$ suhfd. 905097

\title{
KAZANANIN BİR KEZ DAHA ÖDÜLLENDİRILDİĞİ SEÇIM SİSTEMİ: ÇOĞUNLUK ÖDÜLLÜ SEÇİM SİSTEMİ
}

\author{
Dr. Öğr. Üyesi Abdurrahman TEKİ**
}

Öz

Siyasi partiler, seçimler aracılı̆̆ıyla iktidara sahip/ortak olarak veya en azından mecliste temsil edilerek seçmenlere vermiş oldukları sözleri yerine getirme gayre-ti içerisinde olan yapılardır. Siyasi yarış içerisinde olan bu yapılar, ülke siyaseti-nin işler hale getirilmesi veya etkinleştirilmesi için sürekli seçim usullerini güncelleme arzusu içerisinde olurlar. Bu güncellemelerin arkasında kimi zaman iktidarı kaybetmeme düşüncesi yatmaktadır. Ancak kimi zamanlarda bu güncelleme ihtiyacı bir zorunluluk haline gelmektedir. Siyasi istikrarsızlıkların ve tıkanıklıkların sıklıkla görülmesi, seçim sistemlerinde temsilde adalet aleyhine olacak şekilde bir reforma gidilmesine yol açmaktadır.

Yönetimde istikrar için temsilde adaletten taviz veren seçim sistemlerinden birisi de çoğunluk ödüllü seçim sistemidir. Bu seçim sistemini en öz şekilde, seçmenden en yüksek oyu alarak ödüllendirilen bir partinin, bir de seçim sistemi tarafından ödüllendirilerek ilave milletvekili aldığ 1 sistem şeklinde tanımlamak mümkündür. Bu çalışmada, bu seçim sisteminin uygulandığ 1 ülkelerdeki verilerden hareketle yapılan analizler ile seçim sisteminin ne gibi sonuçlar doğurduğu irdelenerek sistemin daha yakından tanınmasına çalışılmıştır.

* Dr. Öğr. Üyesi, Yalova Üniversitesi Hukuk Fakültesi Anayasa Hukuku Anabilim Dalı, Yalova, Türkiye| Asst. Prof., Yalova university, Faculty of Law, Department of Constitutional Law, Yalova, Turkey.

$\triangle$ tekinabdurrahman@hotmail.com• ORCiD 0000-0003-3041-3941

Atıf Şekli | Cite As: TEKİN Abdurrahman, "Kazananın Bir Kez Daha Ödüllendirildiği Seçim Sistemi: Çoğunluk Ödüllü Seçim Sistemi”, SÜHFD., C. 29, S. 3, 2021, s. 17731811.

İntihal | Plagiarism: Bu makale intihal programında taranmış ve en az iki hakem incelemesinden geçmiştir. I This article has been scanned via a plagiarism software and reviewed by at least two referees. 


\title{
Anahtar Kelimeler
}

Parlamenter Sistem • Koalisyon • Seçim Sistemi • Temsilde Adalet ve Yönetimde İstikrar• Olağanüstü Hal Cumhurbaşkanlığı Kararnamesi

\section{AN ELECTORAL SYSTEM WHICH REWARDS THE WINNER ONCE AGAIN: THE MAJORITY PRIZE SYSTEM}

\begin{abstract}
Political parties are in continual pursuit of updating the election procedures with a view to keeping functional or effective the politics of their country. Sometimes the underlying reason behind such updates might be the concern of not losing the power. On the other hand, these updates can occasionally stem from a necessity and become imperative. Frequently experienced political instabilities and dead-locks can lead to a reform in electoral systems which is injustice in representation.

One of the electoral systems which make concessions to justice in representation for the sake of stability in government is the majority bonus system. This electoral system can be defined, as most concisely as possible, as the system in which a party rewarded with the highest number of votes from the electorate is rewarded once more with prize seats by the electoral system. This study has tried to facilitate better recognition of this electoral system through examining its practical outcomes in the light of the analyses conducted based on the data obtained from the countries where this electoral system is in effect.
\end{abstract}

\section{Key Words}

Parliamentary System • Coalition • Electoral System • Justice in Representation, Stability in Government • Presidential Decree

\section{GİRIŞ}

İnsanoğlu, yaratılış gereği cüz'i iradesi sayesinde ezelden beridir günlük iş ve işlemlerinin her bir aşamasında "bireysel seçimler" yapmakta ve hayatına yön vermektedir. Buna karşın, "toplumsal" manada en önemli haklardan olan yöneticilerin seçimi hususundaki kazanımı, oldukça yakın sayılabilecek bir tarihe kadar elde edemediği görülmektedir. Yunan site devletlerinde belirli bir dönem sadece hür olanlara bahşedilen bu hak, nihayet uzun bir aradan sonra Avrupa'da tekrar kullanılmaya başlanmıştır. Seçim hakkının yeniden gün yüzüne çıkmasının temelinde, meclislerin kurulması ve kanun yapımı başta olmak üzere pek çok konuda güç dengesinin monarklardan meclislere kayması yatmaktadır. Parlamenterlerin halk tarafından seçilmeye başlanması ve seçim hakkının 
tabana yayılması ile seçim sistemleri kurgulanmaya ve güç dengesinin paylaşımı hususunda çekişmeler yaşanmaya başlanmıştır.

İnsanoğlunun büyük bedeller ödeyerek seçme imkanına kavuşmasından bu yana, üzerine en büyük tartışmalar yaptığı konuların ilk sıralarında seçim sistemleri gelmektedir. Günümüze kadar oldukça çeşitli seçim sistemlerinin kurgulandığı gözlemlenmektedir. Kullanılan oyları, çeşitli hesaplama yöntemleri ile sandalyelere dönüştüren seçim sistemleri, ${ }^{1}$ günümüzde, adeta bir ağacın dalları gibi budaklanmış ve çeşitlenmiş durumdadır. Her geçen gün, yeni bir sistemin kurgulandığı akademik çalışmalar veya siyasi söylemler ile karşılaşmak mümkündür. Sistemler iç içe geçirilerek yeni sistemler üretilmekte ve hangisinin daha iyi sonuç vereceği üzerinde derin çıkarımlar yapılmaktadır. Bu üretim faaliyetlerinin yegane ve nihai amacını, iktidar mücadelesi olarak görmek yanlış olmayacaktır. Zira seçim sistemleri, genellikle yapıcısını mutlu edecek şekilde, yani yapıcısını, meclis çoğunluğuna ulaştırması amacıyla inşa edilmektedir. Bu sebeple seçim sistemlerinde reform yapma tartışmaları hiçbir zaman son bulmamaktadır.

Siyasilerin en çok zikrettiği reformların başında seçim reformları gelmektedir. Siyasiler, seçim sistemlerinden duyulan rahatsızlı̆̆ her daim dile getirme eğilimindedirler. Ancak bu reformu gerçekleştirme imkanına kavuştuklarında, bu isteklerinin gittiği gözlemlenmektedir. Zira Mitchell'in da oldukça öz bir şekilde zikrettiği üzere, "siyasi güç" ile "seçim reformu arzusu" arasında ters orantı bulunmaktadır. Siyasi iktidar elinde olmadığında seçim reformu isteğini dillendirirsin; söz konusu seçim sistemi ile iktidarı elde ettiğinde ise reform hevesini kaybedersin. ${ }^{2}$ Söz konusu ironik durumdan hareketle ortaya koyulan bu rasyonel çıarımın varyasyonlarını, esasen siyasetin her alanı için türetmek mümkündür. Peki, iktidara gelenlerin seçim reformu yapma hususunda arzusu gidiyorsa, her yıl bir başka ülkeden duyulan seçim sistemi değişikliği haberleri nasıl açıklanmalıdır? Bunun ise cevabı oldukça basittir: Güç kaybeden iktidarlar, koltuklarını daha sağlama almak için reform yapma eğilimine sahip olurlar. Elbette ki adaletsizliklere yol açan mevcut seçim sisteminin,

REYNOLDS, Andrew, REILLY, Ben, The International IDEA Handbook of Electoral System Design, SRM Production Services, Malaysia, 2002, s. 4.

2 MITCHELL, Paul, The United Kingdom: Plurality Rule Under Siege, The Politics of Electoral Systems, Ed. by. GALLAGHER, Michael, MITCHELL, Paul, New York, Oxford University Press, 2005, s. 174. 
siyasi bir patlama noktasına geldiği durumlarda da iktidarlar, kendilerini feda etme pahasına reform yapabilmektedirler.

Siyasi partilerin en önemli amaçlarından birisi, seçmenlere vermiş oldukları sözleri hayata geçirmek için mecliste çoğunluğu elde etmektir. Özellikle parlamenter sistemlerde hayati olan meclis çoğunluğu sayesinde yasama içinden çıkan yürütme, politikalarını rahat bir şekilde icra edebilme imkanına kavuşmaktadır. Başkanlık ve yarı başkanlık sistemlerinde de halk tarafından seçilen devlet başkanı, meclis desteği ile seçmenlerine verdiği sözleri "daha hızlı" bir şekilde yerine getirebilmektedir. Bu sebeple hükümet sistemine bakılmaksızın her ülkede, toplumsal yönelimler analiz edilerek, seçim sistemleri kurgulanmakta ve yönetimde istikrarı temin edecek bir seçim sistemine sahip olmaya çalışılmaktadır. Öte yandan seçim sistemleri kurgulanırken, temsilde adalet ilkesi de elbette ki hesaba katılmaktadır. Bu iki zıt ilkenin makul bir ağırlıkta tutulduğu seçim sistemleri, halkın mutluluk kaynağı haline gelmektedir. Ancak siyasi istikrarsızlıkların had safhaya ulaştığ kimi ülkelerde terazinin dengesi yönetimde istikrar lehine bozulmaktadır. Seçim barajının yükseltilmesi, seçim ittifaklarına imkân verilmemesi, seçim çevrelerinin daraltılması gibi enstrümanlar ile bu istikrar sağlanmaya çalışılmaktadır. Bu noktada, yakın geçmişte parlayan bir seçim sistemini de bu enstrümanlar arasına ilave etmek mümkündür. Meclis çoğunluğunun elde edilmesi mücadelesini, temsilde adalet aleyhine bozmak üzerine tesis edilen ve koalisyonları bitirmek üzere tasarlanan bu sistem, "çoğunluk ödüllü" seçim sistemi olarak isimlendirilmektedir. Bu seçim sistemi ile siyasi istikrarsızlıklardan dolayı etkin faaliyet gösteremeyen yasama ve yürütme organı, temsilde adalet ilkesinin nispeten feda edilmesi ile daha işler hale getirilmeye çalışılmaktadır.

Bu çalışmada böylesi bir seçim sistemine neden ihtiyaç duyulduğu; bu sistem ile ne elde edilmeye çalışıldığı ve edildiği; sistemin, ülke siyasetinde ne gibi etkilere yol açtığı hususları ele alınacaktır. Seçim sisteminin ülkeden ülkeye değişen farklı sonuçlarının bulunması doğal bir durumdur. Bu sebeple farklı ülkelerdeki ulusal düzeydeki uygulamalar ve seçim sonuçları ışığında daha derli toplu bir analiz yapılabilmesi için seçim sisteminin ülkelerdeki uygulamaları ayrı ayrı ele alınacaktır.

\section{I.ÇOĞUNLUK ÖDÜLLÜ SEÇIMM SİSTEMİ: TANIM, TARİHÇE, KAVRAM-SINIFLANDIRMA}

Parti ve adayların seçimlerde almış oldukları oyların çeşitli matematiksel hesaplama yöntemleri yoluyla sandalyelere çevrilmesi seçim 
sistemlerinin başlıca rolüdür. Seçim sistemlerinin bu temel role ilaveten, temsilde adaleti sağlamak ve yönetimde istikrarı temin etmek gibi başka amaçlara ulaşma rolü de bulunmaktadır. Bu amaçları gerçekleştirmek için çeşitli enstrümanlar ile seçim sistemleri donatılmaktadır. Ulusal veya yerel seçim barajı, geniş veya dar/daraltılmış seçim çevrelerinin belirlenmesi, tercihli veya blok liste uygulamaları, seçim ittifakına izin verilip verilmemesi ve seçim çevrelerinin Gerrymandering metodu ${ }^{3}$ ile bölünmesi gibi enstrümanların kullanıldı̆̆ı görülmektedir. İtalya' da başlayıp gelişen bir seçim sistemi ile söz konusu enstrümanların da ötesinde bir seçim sistemi geliştirilmiştir. Bu seçim sisteminde, seçimden birinci çıkan partiye/seçim ittifakına normal şartlar altında kazandığından daha fazla sandalye, adeta bir ödül olarak verilmektedir. Bu seçim sisteminin amacl, mecliste güçlü bir çoğunluğun oluşmasını temin etmektir.

Söz konusu seçim sisteminin doğuşunu, İtalya'nın Faşist lideri Mussolini döneminde görmek mümkündür. O dönemde kaleme alınan bu seçim kanunu, Legge Acerbo, yani yapıcısının soyadını alarak Acerbo Kanunu olarak isimlendirilmiştir. Ancak bu yasa literatürde "dümen, dolandırıcılık, dolap, düzenbazlık kanunu" gibi ağır ithamlar ile nitelendirilmektedir. ${ }^{4} 1923$ yılında çıkarılan bu kanun ile iktidarını sağlamlaştıran Mussolini, İtalya Meclisi'nin 2/3'ünün sahibi olmuştur. Şöyle ki bir parti $\% 25$ 'ten fazla oy almak kaydıyla seçimden birinci çıktığ 1 takdirde mecli$\sin 2 / 3$ 'ünün sahibi olmaktadır. Kalan 1/3 ise diğer partiler arasında bölüştürülmektedir. Acerbo Kanunu, karma bir seçim sistemi öngörmüştür. Birinci olana, çoğunluk seçim sistemi mantığında bir dağıtım yapılırken; diğer partilere nispi temsil esasına uygun bir paylaşım öngörmüştür ${ }^{5}$ Söz konusu seçim sistemi, 1953 yıllında \%50'yi geçen partinin meclisin 2/3'üne sahip olacağ1 şekilde tekrar kurgulanmıştır. ${ }^{6}$ Ancak şartlı ödülün

3 Seçim çevrelerinin bölünmesi sırasında ilçelerin, kasabaların veya mahallelerin idari sınırları dikkate alınmadan zik-zak çizilerek sınırların belirlenmesidir. Bu metodun kullanılması ile ulaşılmak istenen temel amaç, bir adayın veya partinin söz konusu bölgede avantajlı konuma getirilmesidir. Oy deposu olarak görülen bir ilçenin, avantaj sağlaması amacıyla, bir başka seçim çevresine dahil edilmesi sıklıkla karşılaşılan bir durumdur.

4 BEDOCK, Camille, SAUGER, Nicolas, Electoral Systems with Majority Bonus as Mixed Systems Congrès AFSP, 2013, s. 4.

5 MORGAN, Philip, Italian Facism 1915-1945, 2. bs., New York, Palgrave Macmillan, 2004, s. 82.

6 RENWICK Alan, The Politics of Electoral Reform: Changing the Rules of Democracy, Cambridge: Cambridge University Press, 2010, s. 113. 
olduğu bu seçim sistemi ile yapılan seçimde, hiçbir parti \%50'ye ulaşamayarak sandalye dağıtımı nispi temsil sistemine göre yapılmıştır. ${ }^{7}$ İtalya' da yerel düzeyde 1950 yılında uygulanan çoğunluk ödüllü seçim sistemi, kaldırılmış ancak 1993 yılında tekrar getirilmiş ve bu güne kadar da uygulanmaktadır. Fransa' da da bu sistemin yerel seçimlerde 1983' den beri uygulandı̆̆ görülmektedir. ${ }^{8}$

Çoğunluk ödüllü seçim sistemini ulusal düzeyde ikinci uygulayan ülke olarak karşımıza Meksika çıkmaktadır. 1988-1994 tarihleri arasında iki seçimde uygulanan bu sistem, gelen yoğun eleştiriler karşısında kaldırılmıştır. Meksika Devriminden sonraki Maximato olarak isimlendirilen geçiş döneminden beri 60 yıldır başkanlık ve meclis çoğunluğunun tek sahibi olan Kurumsal Devrimci Partisi (PRI), bu seçim sistemini hayata geçirmiştir. PRI'nın başkanlık seçimlerini kazanmayı olası görmesine rağmen, parlayan muhalefet partilerinin varlığı sebebiyle meclis desteğinden yoksun kalacağını düşünmesinin, bu reformun yapılmasına sebep olduğu zikredilmektedir. Yapılan reformda \%50 den bir fazla oy alan parti 500 kişilik meclisin 251 üyesine sahip olacaktır. Partinin oyları arttıkça elde edeceği sandalyenin de artacağ ile PRI, 260 sandalyenin sahibi olmuştur. 1991 yılında yapılan değişiklik ile "çoğunluğu garanti eden seçim sistemi", "çoğunluğu kolaylıkla garanti eden seçim sistemi" olarak isimlendirilmeye başlanmıştır. Buna göre 251 milletvekiline sahip olmak için gereken nisap \%35'e düşürülmüş ve bu orandan fazla alınan her bir yüzde için ilave vekillik temin edilmiştir. ${ }^{9}$ Muhalefetin var olmasına ket vuran bu tarz hükümlerin olduğu seçim sistemi en sonunda kaldırılmıştır. Bahsedilen bu tecrübeler ile sistemin kurgulanmasında birtakım değişikliklere gidilerek XXI. yüzyılda bu seçim

7 DIPARTIMENTO PER GLI AFFARI INTERNI E TERRITORIALI, Camera 07/06/1953 Area Italia, 2021, elezionistorico.interno.gov.it/index.php?tpel=C\&dtel=07/06/1953\&tpa=I\&tpe=A\&lev0=0\&levsut0=0\&es0=S\&ms=S, (E. T. 19.01.2021).

8 BEDOCK, Camille, SAUGER, Nicolas, Electoral Systems with Majority Bonus as Unconventional Mixed Systems, Representation, 2014, C. 50, S. 1, s. 101-102; BEDOCK, SAUGER, 2013, s. 2-4.

9 HORCASITAS, Juan Molinar, WELDON, Jeffrey A., Reforming Electora 1 Systems in Mexico, Ed. SHUGART, Matthew Soberg, WATTENBERG, Martin P., Mixed-Member Electoral Systems The Best of Both Worlds?, Oxford, Oxford University Press, 2001, s. 214-218; POLITCAL DATABASE OF AMERICAS, United Mexican States Election Results, https:/Politi/pdba.georgetown.edu/Elecdata/Mexico/mexico.html (E. T. 20.02.2021). 
sisteminin tekrar uygulamaya koyulduğu görülmektedir. İlerleyen başlıklarda ülkelerdeki uygulamalardan daha detaylıca bahsedilecektir.

Çoğunluk ödüllü seçim sisteminin isimlendirilmesine geçmeden önce seçim sisteminin değişik görünümlerine kısaca değinmek gerekecektir. Bu sistemin birinci çeşidinde, seçimlerde birinci olan partiye, seçim kanununda belirlenmiş sayıda milletvekilliği ödül olarak verilmektedir. Yunanistan' da uygulanmakta olan bu sistemde bu sayı 50 milletvekili olarak belirlenmiştir. Seçim sisteminin ikinci çeşidinde ise seçimlerde birinci olan partiye, meclisteki sandalyelerin \%50'sinden bir miktar fazlası verilmektedir. Bu seçim çeşidi ise 2018'e kadar İtalya'da ve halen San Marino' da uygulanmaktadir.

Yunanistan'daki seçim sistemi için "bonus/ödül" sistemi isimlendirmesi yapılmaktadır. Bu seçim sisteminin, seçimlerde çoğunluğu elde edene, bonus/prim/ödül/ikramiye verildiği seçim sistemi olarak anlaşılması mümkündür. Ancak San Marino, İtalya ve Meksika'daki sistem için "çoğunluk garantili" seçim sistemi isimlendirmesi daha doğru olmaktadır. Bu ülkelerdeki seçim sistemlerinde, gerçekten de meclis çoğunluğunu garanti eden ve kazanan parti/ittifakın, koalisyonsuz hükümet kurmasına veya meclise hâkim olmasına imkân veren bir sistem kurgulandığı görülmektedir. Esasen Yunanistan'da kurgulanan ödül sistemi, partilerin meclis çoğunluğunu garantilemesi ümidiyle kaleme alınmıştır. Ancak bu seçim sistemi, ileride inceleneceği üzere uygulanan 7 seçimin sadece 3 'ünde bir partiyi meclis çoğunluğuna ulaştırmıştır. Buradan anlaşılmaktadır ki Yunanistan'daki seçim sistemi çoğunluk garantili olmayabilmektedir. Bir diğer ifade ile her ne kadar her iki çeşit seçim sisteminde de amaç, meclis çoğunluğunun garantilenmesi olsa da Yunanistan'daki ödül sisteminde bu her zaman mümkün olmamaktadır. Bu sebeple bu iki seçim sistemi için tek bir ad olarak "çoğunluk garantili seçim sistemi" denilemez. Bu iki benzer seçim sisteminin, seçim sonuçlarındaki olası farklılıklar sebebiyle isimlendirmelerinin de farklı olması normaldir. Ancak özü aynı olan bu iki benzer seçim sistemini tek bir "çatı kavram" altında incelemek daha yerinde olur. Bu sebeple iki farklı görünüme sahip seçim sistemi için "çoğunluk ödüllü" seçim sistemi isimlendirmesi tercih edilmiştir. Burada kullanılan "çoğunluk" kelimesi, meclis üye tamsayısının bir fazlasını elde etme olarak değil, genel seçimlerden basit çoğunluk da olsa en fazla milletvekilinin kazanılması olarak anlaşılmalıdır. Yani çoğunluk ödüllü seçim sistemi denilince, seçimde birinci çıkan parti/ittifaka ilave sandalye verildiği anlaşılmaktadır; birinci çıkan parti/ittifakın meclis çoğunluğuna 
ulaştırılması anlaşılmamalıdır. Bu çatı kavramın nitelediği seçim sistemi ile meclis çoğunluğuna da ulaşılması mümkündür; ama bir zorunlu unsur olarak görülmemelidir.

Çoğunluk ödüllü seçim sistemi için alışılmadık, olağandışı veya incognitia nitelendirmelerini yapmak mümkündür. Bu sistemin, uygulandığı ülkeye göre sınıflandırma yapılması daha doğru sonuçlar verecektir. Bilindiği üzere seçim sistemleri çoğunluk ve nispi temsil sistemleri etrafında yapılanmaktadırlar. Günümüzde her iki sistemden de belirli unsurların alındığı karma seçim sistemlerinin yaygınlaştığı görülmektedir. Peki, çoğunluk ödüllü seçim sistemini nereye konumlandırmak gerekmektedir? Bu seçim sistemi için nispi temsil sisteminin bir alt dalı vurgusu yapılmaktadır. Uygulamadan örnek vermek gerekirse, Yunanistan'daki sistem için güçlendirilmiş nispi temsil sistemi; İtalya' daki sistem için ise ödüllü nispi temsil sistemi isimlendirmesinin yapıldığı görülmektedir. ${ }^{10}$ Ancak bu nitelemeler iki farklı aşamadan oluşan bu seçim sisteminin tek bir aşaması üzerinden yapılan eksik değerlendirmeye dayanmaktadir.

Çoğunluk ödüllü seçim sistemi iki farklı aşamadan oluşmaktadır. Bu seçim sisteminin birinci aşaması, milletvekilliklerinin belirlenen kurallara göre normal olarak dağıtıldığı safhadır. İkinci aşaması ise birinci aşamada belirlenen seçim birincisinin, "ödül olarak belirlenen milletvekilliklerini" kazandığı safhadır. Seçimde en çok oyu alan parti/ittifakın ödül milletvekilliklerini kazanmasını değerlendirmek gerekirse eğer (ikinci aşama), bu taksimata çoğunluk sistemi demek gerekecektir. Zira çoğunluk sisteminde parti, aday veya ittifak, belirlenen bir bölgede en fazla oyu aldığı zaman, o bölgede nispi olmayan bir taksimat ile tüm adaylıkları kazanmaktadır. Çoğunluk ödüllü seçim sisteminde de birinci çıkan parti, ülkeden ülkeye değişmekle birlikte, 50 vekil veya meclisin çoğunluğu için belirlenmiş bir sayıya ulaşana kadar eksik kalan milletvekilliklerinin hepsini kazanmaktadır. Ancak sırf bu aşamada yapılan paylaşımı esas alarak bu seçim sisteminin tamamına çoğunluk sistemi denilmesi pek de doğru olmayacaktır. Ödül olarak verilmeyen sandalyelerin nasıl dağıtıldığına bakıldığında ise -ileride teferruatlandırılacağı üzere- genellikle nispi temsil sistemi ile sandalyelerin dağıtıldığı görülmektedir. Sadece bu aşamaya bakılarak bu sisteme nispi temsil isimlendirmesi yapmak da doğru değildir. Çoğunluk ödüllü seçim sisteminin her iki aşaması bir arada 
düşünülerek sınıflandırmasının yapılması gerekmektedir. Bu durumda çoğunluk ödüllü seçim sistemi için iki ana seçim sisteminden esintiler taşıyan bir "karma seçim sistemi" olduğu çıkarımı rahatlıkla yapılabilmektedir.

\section{II. ÇOĞUNLUK ÖDÜLLÜ SEÇIM SİSTEMININN TERCİH SEBEBİ VE ORTAYA ÇIKARABİLECEĞİ SONUÇLAR ${ }^{11}$}

Parlamenter sistemlerde yürütme yasamanın güvenoyuna dayanmaktadır. Gerek göreve gelişte gerekse de görevde kalış süresince yürütmenin, yasama çoğunluğunu kaybetmemesi gerekmektedir. En azından azınlık hükümeti olarak yürütmenin, yasama çoğunluğunun desteğinden yoksun olmaması beklenmektedir. Aksi takdirde mevcut hükümet yıkılacak ve uzunca sürebilecek pazarlıkların gözleneceği hükümet kurma çabalarına girişilecektir. Türkiye'de koalisyon hükümetlerinin yaşandığ1 1990-2002 yılları incelendiğinde 11 hükümetin kurulduğu görülecektir. Yakın tarihten örnek vermek gerekirse 13 partinin mecliste yer aldığ 1 Hollanda' da 2017 yılında yaklaşık 250 gün sonra hükümet kurulabilmiştir. İsrail'de ise Nisan ve Eylül 2019'da, Mart 2020 ve Mart 2021'de hükümet kurulamadığı için erken seçimler yapılmıştır. ${ }^{12}$ Pek çok ülkenin verilerinden, parlamenter sistemlerde hükümet yıkma-kurma mücadeleleri sebebiyle her yasama döneminde aylar hatta yıla yaklaşan sürelerin pazarlıklarla harcandığı rahatlıkla ortaya konulabilecektir. Hükümet krizlerine sebep olarak seçim sistemi, baraj, iktidar/muhalefet partilerinin başarısızlığı, sosyo-politik değişimler, yeni partilerin kurulması gösterilebilir. Ancak sebep hangisi olursa olsun, faturanın kesildiği unsur genellikle değişmemektedir: Seçim sistemleri. Lisi ve Tsatsanis'in de altını çizdiği üzere yönetimdeki istikrarsızlıklar ve halkı tatmin etmeyen politikaların icra

11 Çoğunluk ödüllü seçim sisteminin benimsenmesinde ileride incelenecek olan ülkelerin her birinde aynı saiklerin etkili olduğu göze çarpmaktadır. Buna karşın bu başlık altında sadece genel saikten bahsedilecektir. Bu ülkeleri reforma götüren süreçteki detayların, her ülkenin anlatılacağı alt başlıklara bırakılması konunun daha derli toplu incelenmesi açısından faydalı olacaktır. Aynı şekilde bu seçim sisteminden çıkabilecek sonuçları da genel hatlarıyla bu başlık altında işlemek ve ülke özelindeki detayları ilgili başlık altında incelemek daha uygun olacaktır.

12 TBMM, Hükümetler Listesi, 2021, tbmm.gov.tr/kutuphane/e_kaynaklar_kutuphane_hukumetler.html, (E. T. 10.01.2021); AA, "Hollanda'da 200 gündür hükümet kurulamadı", https://www.aa.com.tr/tr/dunya/hollandada-200-gundur-hukumetkurulamadi/924214, (E. T. 17.03.2021); RASGON, Adam, Israel Has Its 4th National Election in 2 Years. Here's Why, https://www.nytimes.com/2021/03/17/world/middleeast/israeli-election.html, (E. T. 17.03.2021). 
edilmesi, mevcut partilerin toplumdaki değişime ayak uyduramaması ile birleşince yeni partilerin ortaya çıkması kaçınılmaz olmaktadır. Durum bu şekilde geliştiğinde oyların bölünmesi söz konusu olmakta ve istikrarsızlığın daha da artmaması için yönetimdeki siyasi elitler, seçim reformu yapmaya tevessül etmektedirler. ${ }^{13}$

Çoğunluk ödüllü seçim sisteminin temel hareket noktası ve en belirgin amacı yasamada güçlü bir parti/ittifak ve yürütmede istikrarlı bir yönetim ortaya çıkarmaktır. Yönetimde istikrarsızlığın yaşanma potansiyeli yüksek olan parlamenter sistemlerde genellikle görülen bu seçim sistemi ile parçalı bir meclis görünümünden kaçma imkânı doğmaktadır. Seçimden birinci çıkan parti/ittifaka verilecek olan ödül milletvekillikleri ile bu parti/ittifakın kolaylıkla hükümet kurması sağlanmaktadır. İleride verilecek olan bilgiler ile destekleneceği üzere İtalya, San Marino ve Yunanistan' da bu amaçlar ile seçim sisteminin benimsendiği görülmektedir. $\mathrm{Bu}$ ülkelerde yaşanan siyasi krizler ve tıkanıklıklar ve bunların mevcut seçim sistemi ile daha da derinleşeceğinin öngörülmesi, çoğunluk ödüllü seçim sistemine geçişe neden olmuştur.

Çoğunluk ödüllü seçim sisteminin ortaya çıkaracağı sonuçlara bakıldığında, ödül ile desteklenen bir partinin yanı sıra muhalefette kalan ikinci büyük etkin bir partinin varlığı göze çarpmaktadır. Seçmenlerin vermiş oldukları oyların mecliste çoğunluğa ulaşması ve iktidara sahip olmayı istemeleri sebebiyle iki büyük parti çatısı altında seçmenlerin birleşme eğilimleri görünmektedir. Bu noktada seçmenlerin aklında, çoğunluk seçim sisteminde olduğu gibi oylarının israf olmaması düşüncesinin yattığı söylenebilir. Ülkeler incelendiğinde de iki büyük parti etrafında seçmenlerin toplandığ 1 ve eski seçim sistemlerinden elde edilen sonuçlara göre mecliste bulunan etkin siyasi parti sayısında da azalmanın olduğu görülmektedir. San Marino'da ileride görüleceği üzere seçimlerde ve mecliste iki partinin ağırlığı bulunmaktadır. Nitekim İtalya'da iki büyük partinin ödülü almak için mücadele ettiği ve diğer partilerin bu iki büyük parti etrafında birleştiği görülmektedir. Ayrıca İtalya' da etkili siyasi parti sayıları, 1986-2007 yılları arasında 5,5-5,9 arasında iken söz konusu seçim sistemi sayesinde bu oran, 2008-2016 arasında 3,86'ya düşmüştür.

13 LISI, Marco, TSATSANIS, Emmanouil, Southern Europe and the eurozone crisis: political representation, party system characteristics and the impact of austerity, Ed. FREIRE, André, BARRAGAN, Mélany, COLLER, Xavier, LISI, Marco, RIVAS, Cristina, TSATSANIS, Emmanouil, Political representation in Southern Europe and Latin America: Crisis or Continuing Transformation?, New York, Routledge, 2020, s. 6. 
Yunanistan' da da benzer şekilde iki büyük partinin varlığı gözükmüş ancak etkin siyasi parti sayısı bakımından tam tersi sonuçlar elde edilmiştir. 1996-2007 yılları arasında 2,9 olan etkili parti sayısı 2007-2019 yılları arasında 3,26' ya çıkmıştır. ${ }^{14}$ Her ne kadar ileride zikredilecek olsa da Yunanistan'da yaşanan bu artışı, yaşanan ekonomik kriz ve mülteci krizi ile birleştirip, son yarım asra damga vuran iki büyük partinin bu krizleri iyi yönetememesi sebebiyle seçmenlerin başka partilere kayması şeklinde görmek mümkündür. Zira Yunanistan'daki birinci partiye verilen 50 milletvekili ödülünün olmadığını ve bu sayının diğer partilerle paylaşıldığı düşünülürse etkili parti sayısı yukarıda zikredilenden daha da fazla olacaktır. Bu sebeple Yunanistan'da yaşanan etkili siyasi parti sayısındaki artış1, seçim sisteminden kaynaklı "görmemek" gerekir. Bilakis ödül sayesinde bu etkililik sayısında azalma görülmüştür. Netice olarak Yunanistan'daki veriler, "bu seçim sistemi etkili siyasi parti sayısını azaltır veya seçmenleri iki büyük parti etrafında toplar" çıkarımını ortadan kaldirmaya yetmemelidir.

Ancak etkili parti sayısında beklenen azalmanın, meclise giren parti sayısında artışı engellemediği gözlemlenmektedir. Bir diğer ifade ile bu seçim sistemi, kutuplaşmış iki ana akımı doğurmakta ancak bölünmeyi de hızlandırmaktadır. Bu bölünmeye sebep olarak da seçim barajının düşük tutulması gösterilmektedir. Zira bu seçim sistemi temsilde adaletsizlikler oluşturduğu için yüksek bir barajın uygulanmadığı göze çarpmaktadır. Bu sebeple pek çok parti, iktidardan pay alabilme yarışı içerisine girmeye çekinmemektedir. ${ }^{15} \mathrm{Bu}$ seçim sistemi ile partilerin seçime ittifak yaparak girdiği ve seçimi kazanan ittifakların 3-5 partiden oluştuğu görülmektedir. Örneğin İtalya'da 2008 yılında kurulan 60. Hükümet’te, seçimi kazanan ittifakta yer alan 7 parti arasında bakan ve müsteşar dağ1tımı gerçekleşmiştir. ${ }^{16}$ Söz konusu ödüle ulaşmak için küçük partilere

14 GALLAGHER, Michael, 2017, “Election Indices Dataset”, https://www.tcd.ie/Political_Science/people/michael_gallagher/ElSystems/Docts/ElectionIndices.pdf, (E. T. 10.03.2021), s. 18-23; LISI/TSATSANIS, s. 12.

15 BEDOCK/SAUGER, 2014, s. 103-105.

16 Her ne kadar seçimi 3'lü ittifak kazanmış olsa da kendi isim ve amblemleri ile seçime girmeyip, bu 3 parti içerisinde seçimlere katılan partiler de bulunmaktadır. Bu sebeple iktidarın 7 parti arasında bölüşüldüğü görülmektedir. 60. Hükümetin Bakanlar Kurulu listesi için Bkz. GOVERNO ITALIANO PRESIDENZA DEL CONSIGLIO DEI MINISTRI, Governo Berlusconi IV, governo.it/it/i-governi-dal-1943-ad-oggi/xvilegislatura-dal-29-aprile-2008-al-23-dicembre-2012/governo-berlusconi,

(E. T. 10.01.2021). 
duyulan ihtiyaç, seçimlere daha fazla partinin girmesine yol açmaktadır. Nitekim San Marino' da çoğunluk ödüllü seçim sisteminin uygulanmadan önceki iki seçimde "seçimlere katılan parti sayısı" 2001'de 6, 2006'da 9 iken; 2012' de 11'e, 2016' da ise 14'e çıkmıştır. "Mecliste temsil edilen" parti sayısında" da benzer rakamları görmek mümkündür. ${ }^{17}$

Çoğunluk ödüllü seçim sisteminin temsilde adaletten ödün verdiği hususuna da değinmek gerekmektedir. Bedock ve Sauger, bu sistemin çoğunluk seçim sisteminden daha da adaletsiz sonuçlar çıkartacağını zikretmektedir. ${ }^{18}$ San Marino'da birinci partiye meclisin \%58,33'ü, İtalya'da

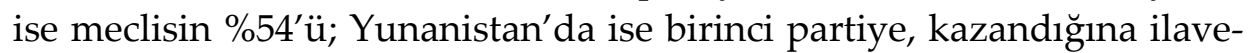
ten \%16,66 ödül milletvekilliği verilmektedir. İtalya'da 2013 yılında seçimi birinci bitiren partinin \%29,55 oy oranı ile meclisteki sandalyelerin \%54'üne sahip olması temsilde adaletsizliği gözler önüne sermeye yetmektedir. ${ }^{19}$ Ancak bu aşırılığın sebebini ödül sisteminin bir şarta bağlanmamasında görmek mümkündür. Nitekim, ileride zikredileceği üzere İtalya'da, yapılan reform ile birinci partinin söz konusu ödülü ancak \%40'tan fazla oy aldığı takdirde hak edebileceğine dair hüküm getirilerek temsilde adaletsizlikler yumuşatılmıştır.

Bu seçim sisteminin, seçim ittifaklarına imkân verecek şekilde işletilmesinin temsilde adaletsizlikleri azaltacağ ${ }_{1}$ unutulmamalıdır. ${ }^{20}$ Zira tek bir parti yerine ittifak içerisindeki partilerin belirlenen ödülü alması ve paylaşması temsilde adaletsizliği hafifletmektedir. Ancak unutulmamalıdır ki temsilde adaletsizlik, sadece seçim sisteminden kaynaklanmamaktadır. Ayrıca seçim çevrelerinin büyüklüğü ve seçim çevrelerinin sınırları, partilerin stratejisi, seçmenlerin koordinasyonu gibi sebeplerle de adaletsizlikler ortaya çıkabilmektedir. ${ }^{21}$

Çoğunluk ödüllü seçim sisteminin temsilde adaletsizliğinin çoğunluk seçim sisteminden dahi öte olduğu çıkarımını eleştiren yazarlar da bulunmaktadır. Bu noktada en önemli eleştiriyi D'alimonte

17 CARR, Adam, Most Serene Republic of San Marino, 2021, psephos.adam-carr.net/countries/s/sanmarino/, (E. T. 10.03.2021).

18 BEDOCK/SAUGER, 2014, s. 99-100.

192013 seçim sonuçları için Bkz. DIPARTIMENTO PER GLI AFFARI INTERNI E TERRITORIALI, Camera 24/02/2013 Area Italia, elezionistorico.interno.gov.it/index.php?tpel=C\&dtel=24/02/2013\&tpa=I\&tpe=A\&lev0=0\&levsut0=0\&es0=S\&ms=S, (E. T. 12.01.2021).

20 BEDOCK/SAUGER, 2014, s. 103-104.

21 BEDOCK/SAUGER, 2013, s. 2. 
getirmektedir. Çoğunluk ödüllü seçim sisteminin, küçük partileri çoğunluk seçim sistemindeki gibi yok saymadığının altını çizmektedir. ${ }^{22}$ Çeşitli ülkelerdeki veriler incelendiğinde D'alimonte'nin haklı olduğu ortaya çıkacaktır. Tek turlu veya iki turlu çoğunluk sisteminde küçük partilerin hak ettikleri sandalyelere ulaşamadığı yaygın karşılaşılan bir durumdur. Örneğin 2017 'de Fransa'da yapılan genel seçimlerin birinci turunda \%2,7 alan Parti Communiste Français (PCF) 10 milletvekili kazanırken; Le Pen'in partisi Front National (FN) \%13,2 ile 8 sandalye kazanabilmiştir. ${ }^{23}$ Halbuki temsilde adalet gereği barajsız ulusal listeli saf nispi temsil sisteminde PCF 13; FN'nin ise 64 milletvekili kazanması gerekirdi. Benzer şekilde İngiltere'de 2019 yılında yapılan genel seçimlerde Liberal Democratic Party (LDP) \%11,6 oy ile 11 sandalye kazanmış; Scottish National Party (SNP) ise aldığ $1 \% 3,9$ oy ile 48 sandalyenin sahibi olmuştur. ${ }^{24}$ Çoğunluk sisteminde bu tip anomaliler ile sıklıkla karşılaşılmaktadır. Ancak düzgün bir şekilde tasarlanmış çoğunluk ödüllü seçim sisteminde "bu denli" adaletsizlikler yaşanmayabilir. Nitekim, çoğunluk ödüllü seçim sisteminde baraj oldukça düşük olduğu için küçük partiler birinci partiden kalan vekilliklerin nispi temsil sistemi ile dağıtılmasından dolayı mecliste temsil imkanına kavuşmaktadırlar. Örneğin, İtalya'da her yüzdelik dilim için 6.3 milletvekilinin kazanılması temsilde adil olanıdır. 2008 seçimlerinde \%1.13 alan ve kazanan ittifak içerisinde olan Movimento per le Autonomie (MpA) Partisi 8 milletvekili kazanmışken; kaybeden muhalefet ittifakında yer alan ve \%4.37 oy alan Di Pietro Italıa Dei Valori (IdV) Partisi 29 milletvekiline sahip olmuştur. ${ }^{25}$ Benzer sonuçları 2013 yılında yapılan seçimden görmek de mümkündür. Seçimlerde \%1,96 oy alan Fratelli D'Italia (FdI) Partisi 9 milletvekili kazanmış; \%4.09 oy alan Lega Nord

22 D'ALIMONTE, Roberto, The New Italian Electoral System: Majority-Assuring But Minority-Friendly, Contemporary Italian Politics, C.7, S. 3, s. 286-292.

23 MINISTERE DE L'INTERIEUR, Résultats des élections législatives 2017, interieur.gouv.fr/Elections/Les-resultats/Legislatives/elecresult_legislatives-

2017/(path)/legislatives-2017//FE.html, (E. T. 15.01.2021).

24 UK PARLIAMENT, General Election 2019: Full Results and Analysis, commonslibrary.parliament.uk/research-briefings/cbp-8749/, (E. T. 15.01.2021).

25 DIPARTIMENTO PER GLI AFFARI INTERNI E TERRITORIALI, Camera 13/04/2008 Area Italia (escl. Valle d'Aosta), 2021, elezionistorico.interno.gov.it/index.php?tpel=C\&dtel=13/04/2008\&tpa=I\&tpe=A\&lev0=0\&levsut0=0\&es0=S\&ms=S,

(E. T. 20.02.2021). IdV'nin kazanmış olduğu milletvekili buradaki resmi sitede 28 olarak gösterilmiştir. Ancak yurtdışından gelen oylar ile seçilen 1 milletvekili daha bu parti tarafından kazanılmıştır. Site içerisindeki "Circoscrizione Estero" sekmesi aracılığıyla yurtdışı oyların dağıtımından alınan bir vekile ilişkin bilgi bulunabilir. 
(LN) Partisi 18 vekil kazanmıştır. ${ }^{26}$ Bir başka sonuca da Yunanistan üzerinden değinmek faydalı olacaktır. Yunanistan'ın nispi temsil sistemindeki seçim sonuçları ile çoğunluk ödüllü seçim sistemindeki seçim sonuçları incelendiğinde, birinci partinin aşkın temsile sahip olduğu gözükmektedir. Ancak diğer partilerin aldıkları oy ile kazandıkları sandalye oranlamasında çoğunluk ödüllü seçim sisteminin beklenenin aksine, eski sisteme göre sandalye dağıtımını temsilde adalete daha yaklaştırdığı göze çarpmaktadır. ${ }^{27}$

Bu noktada seçim sistemi ile ilgili olarak Venedik Komisyonu'nun görüşüne değinerek ülke uygulamalarına geçmek iyi olacaktır. Komisyon, çoğunluk ödüllü seçim sistemi için birinci partiye ayrıcalık tanındığını ancak uygulanmakta olan pek çok seçim sisteminin büyük partileri daha da büyüten sonuçlara sahip olduğunu vurgulamaktadır. Bu sebeple raporda eleştirilerin kısmen haklı olduğunu ancak bu seçim sisteminin uygulanmaması gereken bir seçim sistemi olarak nitelendirilmemesi gerektiği belirtilmiştir. ${ }^{28}$

\section{UYGULAMADAN ÖRNEKLER İLE SEÇIM SISTEMININ DEĞERLENDİIILMESİ}

Bu başlık altında "ulusal düzeyde" çoğunluk ödüllü seçim sistemini uygulamış ve uygulamakta olan ülkelerin XXI. Yüzyıldaki örnekleri irdelenecektir. Ülkeler incelenirken, bu seçim sistemini kabul etmelerine sebep olan siyasi buhranlar, bu seçim sistemi üzerinde yapmış oldukları reformlar, Anayasa mahkemelerinin seçim sistemine ilişkin vermiş olduğu kararlar da göz önünde tutulacaktır. Böylece sistemin, hangi usuller ile uygulandığında nasıl sonuçlar vereceği gözler önüne serilebilecektir. Ayrıca seçim sonuçları analiz edilerek çoğunluk ödüllü seçim sisteminin birincil amacı olan siyasi istikrarı yakalamadaki başarısı da gözlenecektir.

26 DIPARTIMENTO PER GLI AFFARI INTERNI E TERRITORIALI, Camera 24/02/2013 Area Italia, 2021, elezionistorico.interno.gov.it/index.php?tpel=C\&dtel=24/02/2013\&tpa $=I \&$ tpe $=A \& l e v 0=0 \& l e v s u t 0=0 \& e s 0=S \& m s=S$, (E. T. 18.01.2021).

27 PATRIKIOS, Stratos, KARYOTIS, Georgios, "The Greek Parliamentary Election of 2007", Electoral Studies, V. 27/2, 2008, s. 357.

28 EUROPEAN COMMISSION FOR DEMOCRACY THROUGH LAW (VENICE COMMISSION), Report on Electoral Law and Electoral Administration in Europe, 2020, s. 42, venice.coe.int/webforms/documents/default.aspx?pdffile=CDL-AD (2020)023-e, (E. T. 10.03.2021). 


\section{A. İtalya 2006-2019}

İtalya, bulunduğu coğrafyada devletleşme aşamasına en geç geçen ülkelerdendir. Siyasi birliğini ancak 1861 yılında sağlamış ve krallık ilan edilmiştir. Faşist lider Benito Mussoluni'nin diktatörlüğü altında 1946 y1lına kadar 22 yıl yönetilen İtalya, II. Dünya Savaşından mağlup ayrılması neticesinde Faşist rejim yıkılmış ve yerine Cumhuriyet kurulmuştur. Faşist döneme tepki olarak yapılan 1948 Anayasası, yürütme gücünü olabildiğince parçalayan birtakım düzenlemeler öngörmüştür. ${ }^{29} \mathrm{Bu}$ düzenlemelerin başında da iki meclisli bir yapının varlığ 1 gelmektedir. Birçok Avrupa ülkelerine benzer olarak İtalyan Parlamentosunda da iki meclisli bir yapı benimsenmiş ancak bu meclislere neredeyse eş yetkiler tanınmıştır. ${ }^{30}$ Her iki Meclisin de aynı partinin elinde olduğu seçim sadece 1948 yılında gerçekleşmiş, daha sonra yapılan 17 seçim sonucunda parçalı bir meclis yapısı oluşmuş, her iki Meclisi de elinde bulunduran bir partiye rastlanmamıştır. ${ }^{31}$ Anayasa'da öngörülen belirli durumlarda, her iki meclis birlikte oturum yapıp karar alma sürecini yürütmek zorundadırlar. Öngörülen bu simetrik meclis yapısı da sistemi tıkayan ve siyasi istikrarsızlıklara yol açan baş etmenlerden birisidir. ${ }^{32}$ Her iki meclisin de birbirine eş yetkilerle donatılmasının arkasında yatan sebep olarak Mussolini zamanında yaşanan acı tecrübelerle bir daha karşılaşma korkusunun varlığı gösterilmektedir. Yani bir meclisin çok revizyonist ve devrimci bir yapısı olduğunda, bir diğerinin onu dizginlemesi, frenlemesi amaçlanmaktadır. ${ }^{33}$ Tıkanıklığa yol açan hususların bir Anayasa değişikliğiyle

29 SOLAK, Mehmet, “İstikrarsız Hükümetler ve Sürekli Reform Arayışı: İtalya' da Parlamenter Sistem”, Ed. YAPICI KAYA, Havvana, TBMM Araştırma Merkezi Yayınları Karşılaştırmalı Hükümet Sistemleri: Parlamenter Sistem (Almanya, Güney Afrika, Hindistan, İngiltere, İtalya ve Japonya Örnekleri), TBMM Basımevi, Ankara, 2015, s. 246

30 İtalya Anayasası, 1948, m. 70.

31 DIPARTIMENTO PER GLI AFFARI INTERNI E TERRITORIALI, Camera 18/04/1948 Area Italia, (çevrimiçi) http://elezionistorico.interno.it/index.php?tpel=C\&dtel=18/04/1948\&tpa=I\&tpe=A\&lev0=0\&levsut0=0\&es0=S\&ms=S, (E. T. 11.02.2021).

32 GOLDONI, Marco, Italian Constitutional Referendum: Voting for Structural Reform or Constitutional Transformation?, Verfassungsblogon Matters Constitutional, verfassungsblog.de/italian-constitutional-referendum-voting-goldoni/,

(E. T. 02.02.2021).

33 WILLS, Mark, Et Tu, Brute? Is the Italian Referendum the Second Act of the European Union's Tragedy?, 2016, s. 2, https://www.ssga.com/publications/investment-quarterly/2016/et-tu-brute-is-the-italian-referendum-04102016.pdf, (E. T. 11.03.2021). 
aşılamamış olması, ülkenin siyasi istikrarsızlıklara düşme ihtimalini de arttırmaktadır. ${ }^{34}$

İtalya'nın parçalı meclis yapısının ülkede siyasi istikrarsızlığa olan etkisini daha iyi görebilmek için, 1948' den günümüze kadar olan yasama dönemlerinde yapılan kanunlaştırma oranlarına bakmak daha yararlı olacaktır. 1948-1993 yılları arasında iki partili hayatın yoğun olduğu koalisyonlar yaşanmış, iktidar, Hıristiyan Demokrat partisinin elinde bulunmuş, sadece ittifak kurdukları küçük partiler değişmiştir. ${ }^{35} 1993$ Seçim Kanunu değişikliğine kadar süren bu dönemin verileri incelendiğinde, yüksek bir kanunlaştırma oranı görülmektedir. Oran olarak \%65'in altına hiç düşmeyen tasarıların kanunlaştırma oranı, bu 10 yasama döneminde ortalama \%80,5 olarak gerçekleşmiştir. (Bkz: Tablo 1) 1993'te Seçim Kanununda yapılan değişiklikle, daha parçalı bir meclis yapısı doğmuş ve bu da kanunlaştırma oranlarını ve meclise sunulan kanun tasarılarının sayısını bir hayli düşürmüştür. Bu durumun, işlevselliğini yitirmiş ve karar alma yeterliliğinden yoksun bir parlamento görüntüsü verdiği söylenebilir. (Bkz: Tablo 1) Aşağıdaki tablodaki veriler, hükümet tarafından sunulan "kanun tasarılarının" yasalaşma oranıdır. Son yıllara ait verilerden de görülebildiği gibi ittifak halinde hükümette yer alan partiler kanun tasarısını birlikte veriyor ancak hükümetteki ittifakları, meclise yansıyamadan tasarılar reddediliyor çıkarımı yapılabilir. Bu durum da İtalya'nın yasama faaliyetlerinin ne derece istikrarsız yürüdügünü göstermektedir.

342016 yılında Anayasa reformu hazırlanmıştır. Buna göre Senato'nun artık hükümeti ilgilendiren konularda oylama yapma yetkisi kaldırılmış ve böylece eskiden beri uygulanılagelen simetrik çift meclisli yapıdan vazgeçilmiştir. Bkz. CHIARAMONTE, Alessandro, The Unfinished Story of the Electoral Reforms in Italy: The Difficult Attempt to Build a Majoritarian-Style of Government, 2014, http://www.sisp.it/files/papers/2014/alessandro-chiaramonte-1827.pdf, (E. T. 11.03.2021), s. 14-15. Senato, artık hükümetin güven oylamasına katılamayacak ve Temsilciler Meclisinin çıkardığı kanunları veto edemeyecektir. Böylece politik güç, Temsilciler Meclisine bırakılmış olmaktadır. Bu düzenlemenin asıl maksadı, 2013 seçimlerinde yaşanan iki meclisi farklı güçlerin elde etmesinden kaynaklı karmaşık ittifaklardan ve elverişsiz karar alma süreçlerinden ülkeyi uzak tutmaktır. Bkz. STRATFOR, How Electoral Reform Effect Italian Politics, 6 May 2015, https://worldview.stratfor.com/article/how-electoral-reform-will-affect-italian-politics, (E. T. 15.03.2021), s. 1. Ancak bu Anayasa reformu, Aralık 2016'da yapılan referandum ile reddedilerek, siyasi tıkanıklıklara çözüm getirme çabası adeta bir başka bahara bırakılmıştır. 
Tablo $1^{36}$

\begin{tabular}{|l|c|c|c|}
\hline Yasama Dönemi & $\begin{array}{c}\text { Sunulan Kanun } \\
\text { Tasarıs1 }\end{array}$ & $\begin{array}{c}\text { Kabul Edilen } \\
\text { Kanun Tasarıs }\end{array}$ & $\begin{array}{c}\text { Kanunlaşma } \\
\text { Oran1 \% }\end{array}$ \\
\hline I (1948-1953) & 2,199 & 1,996 & 92,8 \\
\hline II (1953-1958) & $\mathbf{1 , 5 6 4}$ & $\mathbf{1 , 4 3 9}$ & $\mathbf{9 2}$ \\
\hline III (1958-1963) & 1,484 & 1,34 & 90,3 \\
\hline IV (1963-1968) & $\mathbf{1 , 4 4 2}$ & $\mathbf{1 , 2 5 9}$ & $\mathbf{8 7 , 3}$ \\
\hline V (1968-1972) & 831 & 663 & 79,8 \\
\hline VI (1972-1976) & $\mathbf{1 , 1 3 3}$ & $\mathbf{9 4 1}$ & $\mathbf{8 3 , 1}$ \\
\hline VII (1976-1979) & 831 & 644 & 77,5 \\
\hline VIII (1979-1983) & $\mathbf{1 , 2 4 2}$ & $\mathbf{8 6 1}$ & $\mathbf{6 9 , 3}$ \\
\hline IX (1983-1987) & 1,175 & 769 & 65,4 \\
\hline X (1987-1992) & $\mathbf{1 , 3 6 9}$ & $\mathbf{9 2 2}$ & $\mathbf{6 7 , 3}$ \\
\hline XI (1992-1994) & 653 & 292 & 44,7 \\
\hline XII (1994-1996) & $\mathbf{8 1 9}$ & $\mathbf{3 1 8}$ & $\mathbf{3 8 , 8}$ \\
\hline XIII (1996-2001) & 1,222 & 695 & 56,9 \\
\hline XIV (2001-2005) & $\mathbf{6 4 6}$ & $\mathbf{4 2 9}$ & $\mathbf{6 6 , 4}$ \\
\hline XV (2006-2008) & 284 & 99 & 34,8 \\
\hline XVI (2008-2013) & $\mathbf{4 8 2}$ & $\mathbf{2 9 8}$ & $\mathbf{6 1 , 8}$ \\
\hline XVII (2013-2015) & 223 & 101 & 45,2 \\
\hline
\end{tabular}

İtalyan seçimleri genel hatlarıyla incelendiğinde, İtalya'daki siyasi istikrarsızlığın ne boyutlara ulaştığının en çarpıcı göstergelerinden bir diğeri ise tek parti iktidarının sadece 1948 yılında görülebilmiş olmasıdır. Seçimden önce yapılan ittifaklarla blok halinde seçime katılımın ilk kez mümkün olduğu 1994 seçimine kadar sürekli koalisyonlar devri olmuştur. 1994 yılından sonraki seçimlerde ise seçim öncesi ittifakın önü açılmış ve seçimleri, ittifak yapan gruplar kazanmıştır. ${ }^{37}$ Ancak bu durum,

36 SOLAK, s. 264.

37 DIPARTIMENTO PER GLI AFFARI INTERNI E TERRITORIALI, 2021, https://elezionistorico.interno.gov.it/index.php, (E. T. 18.03.2021). 
yukarıda da belirtildiği gibi kırılgan bir yürütme organının oluşumuna neden olmuştur. İttifaklar içinde bulunan parti sayısının fazlalığı ve bunlar arasındaki ciddi fikir ayrılıklarından dolayı kanun tasarılarının parlamentodan geçirilemediği gözlenmiştir.

İtalya' daki siyasi istikrarsızlıklar, kurulan hükümetlerin ömründen de anlaşılmaktadır. 1948-1994 tarihleri arasında kurulan hükümetlerin ortalama görevde kalma süresi 322 gün; 1994-2006 yılları arasında 523,4 gün ${ }^{38}$ iken 2006-2021 yıllarında ise yaklaşık 601 gün olarak gerçekleşmiştir. Bu durum, sürekli hükümetlerin yıkılıp yeni pazarlıkların yapılmasına, sonunda da erken seçimlerin yapılmasına sebebiyet vermiştir. İtalya'nın 1948'dan günümüze yaklaşık 73 yıllık siyasi tablosuna bakıldığında 67 farklı hükümetin kurulduğu ve seçimlerin sürekli vaktinden önce yapıldığı, sadece son zamanlardaki yasama dönemlerinde erken seçime gidilmediği görülmektedir.

1993 yılına gelindiğinde sürekli aynı iki partinin seçim sisteminden dolayı iktidarda olması, toplumda rahatsızlıklara neden olmuş ve halkın $\% 77$ 'sinin katılımıla yapılan referandum ile yeni seçim kanunu $\% 82,7$ oy ile kabul edilmiştir. Buna göre 1994 seçimlerinden 2006 seçimlerine kadar uygulanan "karma" bir sistem öngörülmüştür. Bu dönemde 630 sandalyeli Temsilciler Meclisinin 475'i “dar bölgeli basit çoğunluk" usulüne göre, geriye kalan 155 vekil ise "nispi temsil" ile seçilmekteydi. Her partinin 155 kişilik bir liste hazırladığ1 ve seçimden aldığ 1 oyun karşılığ1 olan sayıda vekile sahip olmasına dayanan bu sistemde, düşünülenin aksine, özellikle küçük partiler daha da fazla varlık gösterme imkânı bulmuş ve daha parçalı bir meclis yapısı ortaya çıkmıştır. ${ }^{39} \mathrm{Bu}$ sistemde, yine iki ana partinin ağırlığı hissedilmekle birlikte, hiçbir partinin dar bölgeli basit çoğunluk sisteminde tek başına iktidarı elde edecek kadar vekil çıkarması mümkün olamamış, bu durum da büyük partileri birden fazla partiyle, çok kırılgan olacak olan koalisyonlar kurmaya sevk etmiştir. Görülen sonuçlar ile bu seçim kanununun da yönetimde istikrar sorunlarını çözmeye elverişli olmadığı anlaşılmıştır. ${ }^{40}$

38 CHIARAMONTE, s. 17.

39 ORTONA, Guido, OTTONE, Stefania, PONZANO, Ferruccio, "A Simulative Assessment of The Italian Electoral System”, Department of Public Policy and Public Choice - POLIS, 2005, s. 8.

40 AGNEW, John "Remaking Italy? Place Configurations and Italian Electoral Politics under the Second Republic", Modern Italy, C. 12, S. 1, 2007, s. 25-27 
2005 yılında yapılan yerel seçimlerden mağlup ayrılan Merkez sağ ittifakı (Berlusconi Hükümeti), 2006 yılındaki genel seçimlere mevcut sistemle girdiğinde ciddi sayıda koltuk kaybedeceğini öngörerek, yasama yılının sonuna 6-7 ay kala, seçimleri kolaylıkla kazanacaklarına inandığı bir seçim reformunu parlamentodan geçirmiştir. ${ }^{41} \mathrm{Bu}$ sistemde, seçimde çoğunluğu elde eden partiye veya ittifaka fazladan vekillik verilmesi düzenlenmektedir. 19 seçim çevresinde ve yurtdışındaki vatandaşlar tarafından kullanılan oyların toplamının en çoğunu alan parti veya ittifaka, parlamentodaki 630 sandalyenin 340'ının verilmesi düzenlenmiştir. Bu seçim sisteminde, ilk başta partilerin almış oldukları oylara göre vekillikler dağıtılır. Hiçbir parti veya ittifakın 340 vekil elde edememesi halinde, bu dağıtım işlemi iptal edilir ve en çok oyu almış parti/ittifaka 340 vekil adeta "hediye" edilir. ${ }^{42}$ Ancak bunun için iki çeşit baraj öngörülmüştür. Bunlardan birincisi, hiçbir ittifak yapmadan seçime giren partilerin 340 vekili alabilmesi için seçimden birinci çıkması ve en az \%4 oy alması gerekmektedir. Örneğin seçime onlarca partinin katıldığı ve çoğunun düşük oylar aldığı varsayımında, seçime ittifaksız giren "X" partisi \%4 barajını geçerek birinci olduğunda 340 vekile sahip olacaktır. Görüldüğü üzere, oluşma ihtimali zayıf da olsa oldukça orantısız bir temsil yetkisi veren bir sistem öngörülmüştür. Bir diğer baraj şartı ise ittifak yaparak seçime giren partiler için getirilmiş olan \%10 barajıdır. Buna göre seçim ittifakının seçimlerde birinci çıkması ve en az $\% 10$ oy alması halinde, bu ittifak 340 vekilin sahibi olmaktadır. Böylece çok parçalı bir meclis figüründe \% 11 ile seçimden zafer ile ayrılan örneğin "Y" ittifakı, 340 vekil sahibi olabilecektir. ${ }^{43}$ Bu sistemde geriye kalan 277 koltuk, partilerin almış oldukları oran nispetinde, "nispi temsil" esasına göre dağıtılacaktır. ${ }^{44}$ Siyasi istikrarsızlığa son vermek adına getirilen bu sisteme, "Majority-Assuring/Garantili Çoğunluk Sistemi" adı verilmektedir. ${ }^{45}$ Seçime bağımsız giren partiler için öngörülmüş olan \% 4'lük baraj, küçük partileri büyük partilerle

41 BALDINI, Gianfranco, “The Different Trajectories of Italian Electoral Reforms”, West European Politics, C. 34, S. 3, 2011, s. 654-656.

42 SOLAK, s. 271.

43 FUSARO, Carlo, "Party System Developments and Electoral Legislation in Italy (1948-2009)", Bulletin of Italian Politics, C. 1, S. 1, 2009, s. 57-58.

$44 \quad 340+277=617$ yapmaktadır. Geriye kalan 13 vekilliğin 12 'si yurtdışı seçmenler tarafından verilen oylarla seçilir, 1' i ise 'Valle d'Aosta' adlı seçim çevresinden seçilir.

45 FUSARO, s. 58. 
ittifak etmeye zorlamakta, aksi takdirde barajı geçemeyecekleri için milletvekilliği kazanamamakla karşı karşıya bırakmaktadır.

Bu sistemin ilk uygulandığ 2006 seçimlerinde “The Union” ittifakı (13 partilik bir ittifak) ${ }^{46}$, oyların 19.002.598'unu alarak (\%49,81) 340 milletvekili kazanırken, başını Berlusconi'nin çektiği "House of Freedoms" ittifakı (12 partilik bir ittifak $)^{47}, 18.977 .843$ oy ile (\%49,74) 277 milletvekili kazanabilmiştir. ${ }^{48}$ Seçim sonucu değerlendirildiğinde, neredeyse eşit oy alan iki partinin sahip olduğu vekil sayısında temsilde adalet yönünden büyük bir farklılık mevcuttur. Görülen bu tablo üzerine ilerleyen yıllarda bir tadilat gerçekleştirilmiştir.

Senato seçimlerinde ise bu sistem ulusal düzeyde uygulanmamakta, her bir bölge için ayrı ayrı uygulanmaktadır. Bu da Temsilciler Meclisinde elde edilmesi garanti olan çoğunluğun, Senatoda pek de kolay elde edilemeyeceği sonucunu doğurmaktadır. ${ }^{49}$ Nitekim 2013 seçimlerinde Temsilciler Meclisinde 340 vekil almaya hak kazanan parti, Senatoda çoğunluğu elde edememiştir. Böylece Temsilciler meclisinde hükümeti kuran partiler, Senatodaki çoğunluğu elde edemedikleri için siyasi istikrarı tam manasıyla sağlayamamışlardır.

İtalyan Anayasa Mahkemesi, 2014 yılında vermiş olduğu karar ile Temsilciler Meclisinde ülke çapında, Senato seçiminde bölgesel çapta birinci gelen partiye fazladan vekil verilmesini ve seçmenlere seçim hakkı tanımayan "listeli oy" usulünü düzenleyen kanun maddelerini iptal etmiştir. ${ }^{50}$ Mahkeme, ilgili kanun maddelerinin gerekli minimum oyu alan

46 The Olive Tree, Communist Refoundation Party, Rose in the Fist, Party of Italian Communists, Italy of Values, Federation of the Greens, Union of Democrats for Europe, Pensioners' Party, South Tyrolean People's Party, The Socialists, Consumers' List-Civic Duties-Christian Democracy, League for Autonomy-Lombard AlliancePensioners League, Liga Fronte Veneto

47 Forza Italia, National Alliance, Union of Christian and Centre Democrats, Lega Nord- Movement for Autonomy, Christian Democracy-Socialist Party, Social Alternative, Tricolour Flame, No Euro, United Pensioners, Environmenta-list - Democratic Ecologists, Italian Liberal Party, S.O.S. Italy

48 DIPARTIMENTO PER GLI AFFARI INTERNI E TERRITORIALI, Camera 09/04/2006 Area Italia (escl. Valle d'Aosta), elezionistorico.interno.gov.it/index.php?tpel=C\&dtel=09/04/2006\&tpa=I\&tpe=A\&lev0=0\&levsut0=0\&es0=S\&ms=S, (E. T. 23.02.2021).

49 CHIARAMONTE, s. 7

50 COURTE CONSTITUZIONALE, 2014, para.1, https://dochero.tips/judgment-no-1year-2014.html, (E. T. 21.02.2021). 
bir partinin belirtilen maksimum vekilliğe kavuşmasını sağlamasının demokratik temsilde ciddi bir noksanlığa yol açacağından dolayı, bu hükümlerin Anayasa'nın 1/2, 3, 67. maddelerine aykırılık teşkil ettiğini belirtmiştir. Esasında mahkeme, birinci partinin 340 milletvekili almasının Anayasaya aykırı olduğunu belirtmemiş, sadece bu sayıda milletvekilini kazanabilmek için daha üst bir sınırın belirlenmemesini Anayasaya aykırı bulmuştur. Örneğin ittifakla seçime girildiğinde \%10'u geçen bir partinin birinci olması halinde 340 vekil alması, temsilde ciddi adaletsizliklere yol açacağından, daha üst bir sınırın belirlenmesi gerektiğine vurgu yapılmıştır. Bir diğer deyişle, \%35 veya 40 gibi bir üst sınırı geçen ve birinci olan partinin, 340 vekile sahip olabilmesi gerektiğine vurgu yapılmıştır. Gerçekten de mevcut durumda çok az oy alan bir partinin parlamentoda \%54 gibi bir çoğunluk elde etmesi demokrasi açısından kabul edilebilir bir şey değildir. ${ }^{51}$ Anayasa Mahkemesinin, kanunun ilgili maddelerini iptal etmesi üzerine de facto olarak nispi temsil sistemine girildiğini söylemek mümkündür. Yakın zamanda bir düzenleme yapılmadığı takdirde, İtalya'nın 2018 genel seçimine gireceği sistem 1948-1992 yılları arasındaki sistemle aynı olacaktı. ${ }^{52}$ Geçmişin acı tecrübelerinin tekrar yaşanmaması için Parlamento, 2015 seçim reformunu hayata geçirmiştir.

İtalya'nın yeni Başbakanı Renzi, Anayasa Mahkemesinin 2014'te vermiş olduğu iptal kararı üzerine 2015 yılında yeni bir seçim reformunu parlamentoya sürerek, ülkesini eski istikrarsız günlerine döndürmemeye çalışmıştır. Yeni getirilen sistem, 2005 yılında getirilen ve Anayasa Mahkemesince iptal edilene kadar uygulanan çoğunluk ödüllü karma seçim sisteminin, biraz daha değiştirilmiş halidir. Bu sistemde, 2014 yılında Anayasa Mahkemesinin iptal gerekçesini dayandırdığ1 "üst sınır" eksikliği giderilmiştir. Buna göre seçimde $\% 40$ 'tan daha fazla oy alan ve birinci çıkan parti/ittifak, 630 milletvekilinin olduğu Temsilciler Meclisinde 340 milletvekili elde etmekte, geri kalan milletvekilliklerse "liste usulü nispi temsil" sistemine göre diğer parti/ittifaklara dağıtılmaktadır. Hiçbir partinin \%40'lık barajı aşamaması durumunda ise 2 hafta içinde yapılacak 2. tura, en çok oyu almış iki parti/ittifak girmekte ve geçerli oyların \%50'sinden fazlasını alan parti/ittifaka 340 milletvekili verilmektedir. ${ }^{53}$ Baraj

51 COURTE CONSTITUZIONALE, 2014, para: 3.1, https://dochero.tips/judgment-no-1year-2014.html, (E. T. 21.02.2021).

52 CHIARAMONTE, s. 14.

53 Disposizioni in Materia di Elezione Della Camera Dei Deputati, Legeg 6 Maggio 2015, n. 52, Art: 1/1 (f). 
olarak ise \%3'lük bir "ulusal baraj” öngörülerek siyasi bölünmeler engellenmeye çalışılmaktadır. Bir önceki düzenlemede olan \%4'lük seçim baraj1 \%3'e düşürülerek mecliste temsil edilmeyen oylarda düşüş sağlanmaya çalışılmıştır..$^{54}$

Italicum adı verilen seçim reformunun hayata geçmesinin önündeki en büyük tehditlerden biri, yine Anayasa Mahkemesi olarak görülmekteydi. Mahkemenin 2014 tarihinde, bir önceki seçim reformuyla alakalı olarak vermiş olduğu iptal kararı göz önünde bulundurulunca, bu reform için de iptal kararı verilebileceği düşünülmekteydi. ${ }^{55}$ Ancak Anayasa Mahkemesinin bir önceki reforma ilişkin verdiği iptal gerekçelerini öngören hükümet, eski reforma göre birtakım değişiklikler yapmıştır. Bunun başında, "hediye milletvekilliklerinin" alınabilmesi için \%40'lık bir üst s1nır belirlenmiştir. Eski seçim reformunda halkın, milletvekillerinin sıralamasında bir değişiklik yapamamaktaydı. Böylece halka bir liste dayatılmakta ve tercih imkânı sunulmamaktaydı. Bu konu üzerinde bir değişikliğe gidilmiş ve seçmenlere tercih yapma hakkı getirilmiştir. Böylece seçmenler, kendilerine sunulan blok listede seçim yapma imkânına sahip olmuşlardır. Buna ilaveten reforma, kadın vekil sayısını dengelemek için de birtakım hükümler eklenmiştir. ${ }^{56}$

54 Disposizioni in Materia di Elezione Della Camera Dei Deputati, Legeg 6 Maggio 2015, n. 52, Art. $1 / 1$ (e).

55 STRATFOR, s. 1.

56 Seçim Kanunun 1. maddesinin 1. fıkrasının (a) bendine göre İtalya 20 seçim çevresine bölünmüş ve bunlar da kendi içinde tekrar alt seçim bölgelerine bölünerek nüfuslarına göre 3 ila 9 vekilin bulunduğu toplamda 100 seçim çevresi oluşturulmuştur. Aynı maddenin (b) bendine göre her parti, her seçim çevresi için bir "liste başı ismi" belirlemektedir. Ancak belirlenen 100 "liste başı vekilin" \%60'1 aynı cinsiyetten olamamaktadır. Yani en az 40 kadın veya erkek liste başı olarak belirlenmiş olabilmekte daha fazlasına izin verilmemektedir. Buna ilaveten, seçmenlere her seçim çevresinde iki adayı belirleme hakkı tanınmıştır. Seçmenler, liste başındaki vekil adayına ilaveten, iki ismi daha oy pusulasına yazabilmektedir. Ancak tercih edilen bu iki ismin ikisi de erkek veya kadın olamamakta, en az birisi kadın diğeri de erkek olabilmektedir. Aksi takdirde ilk yazılan isim geçerli, ikinci yazılan isim geçersiz kabul edilmektedir. Yapılan taksimatı bir örnek vererek daha da somutlaştırmak mümkündür. Örneğin, X partisinin 340 vekil kazanıp iktidarı elde ettiğini varsayarsak, partinin belirlediği her seçim çevresi için belirlenen 100 tane "liste başı vekil adayı" doğrudan vekillik hakkını kazanmış olur. Daha sonra partilerin her seçim çevresinde belirlediği adaylar arasından seçmenler tarafından en fazla tercih edilen ikişer aday vekillik hakkı kazanır. Daha sonra da listede belirlenen diğer adaylara sıra gelecek şekilde bir taksimat yapılır. Bkz. Disposizioni in Materia di Elezione Della Camera Dei Deputati, Art. 1/1 (g). 
Ocak 2017'de İtalyan Anayasa Mahkemesi, 2016 y1lındaki anayasa değişiklik referandumunun iptal edilmesini de fırsat bilerek, 2015 seçim reformunun belli hükümlerini iptal etmiştir. İptal edilen en önemli kısım ise hiçbir partinin \%40' 1 geçememesi halinde yapılacak olan 2 . tur oylamalarına ilişkin hükümdür. Anayasa Mahkemesi 2. tura kalan seçimin, temsilde adalet ilkesine aykırı olduğunu ileri sürerek, 2. tur oylamayı düzenleyen hükümleri iptal etmiştir. Böylece seçimler tek turlu olacak ve \%40'ı geçen parti ödül milletvekillikleri kazanacak, hiçbir partinin bu sayıya ulaşamaması halinde ise saf nispi temsil sistemine göre milletvekilliklerin taksimatı yapılacaktır. Anayasa Mahkemesi, seçimde en çok oyu alan iki partinin, 2. turda tekrar seçime girmesinde, herhangi bir üst sınır belirtilmediğini iptal gerekçesi olarak göstermiştir. Örneğin, seçime katılan ve birinci olan partinin oy oranı $\% 15$, ikinci olan partinin oy oranının ise \%10 olduğunu varsayalım. Bu durumda \%40'1 geçen parti olmadığ için 2. tur oylamalara en çok oyu alan bu iki parti girecektir. Anayasa Mahkemesi de işte bu noktada, bu kadar az oy alan bu iki partiden birinin mutlaka 2. turda \%50'yi geçerek 340 milletvekilliği kazanacağını, bu durumun da olağanüstü bir aşkın temsile, haksız kazanca sebebiyet vereceğini ileri sürmüştür. ${ }^{57}$

2017 yılına gelindiğinde ise yapılan seçim değişikliği ile çoğunluk ödüllü seçim sisteminden vazgeçilmiş ve karma seçim sistemi benimsenmiştir. Buna göre milletvekillerinin 1/3'ü çoğunluk seçim sistemine, kalanı ise nispi temsil sisteminin en büyük artık usulüne göre belirlenmektedir. ${ }^{58}$

İtalya'da çoğunluk ödüllü seçim sisteminden önceki, 20 yılı dahi bulmayan zaman zarfında 12 hükümet değişmiş, iki tane "çok fazla partiden oluşan" koalisyon hükümeti kurulmuş, 6 farklı başbakan görev yapmış ve ilginçtir ki aynı yasama döneminde meclis çoğunluğu yer değiştirmiştir. ${ }^{59}$ Uzlaşma kültürünün ve koalisyonlu yapının zenginliği yeteri düzeyde idrak edilememiş olan İtalya'da, ülkenin planladığı reformları

57 DIAN, Schefold, "Constitutional Reform and Constitutional Unity", The Italian Law Journal, Special Issue, 2017, s. 147-156.

58 CHIARAMONTE Alessandro, D'ALIMONTE, Roberto, The New Italian Electoral System and its Effects on Strategic Coordination and Disproportionality, Italian Political Science, C. 13, S. 1, 2018, s. 10.

59 PASSARELLI, Gianluca, Electoral Systems in Context: Italy, Ed. HERRON, Erik S. PEKKANEN, Robert J., SHUGART, Matthew S., The Oxford Handbook of Electoral Systems, New York, Oxford University Press, 2018, s. 860. 
gerçekleştirmesinin tek görünür yolu, istikrarlı ve uzun süreli hükümetlerin kurulmasıdır. Nitekim sunulan reçete çözüm bulmaya yetmemiştir. İtalya' nın tecrübe ettiği çoğunluk ödüllü seçim sistemi üzerine söylenebilecek ilk şey, çoğunluk ödüllü seçim sisteminin arzu edilen neticeyi tam manasıyla verememesidir. Zira sistemin uygulandığı ve bir ittifakın meclisin \%54'üne sahip olduğu 3 seçim yapılmasına rağmen 12 yılda 6 kez hükümet değişmiştir. Bu hükümetlerden biri de partiler üstü teknokrat hükümetidir. Ne var ki çoğunluk ödüllü seçim sisteminden beklenen istikrarlı hükümetlerin İtalya' da arzu edilen düzeyde oluşmamasını, tamamen seçim sistemine mâl etmek doğru değildir. İtalya'da asıl sorun, siyasi partilerin yaklaşımlarından kaynaklanmaktadır. Zira seçim sisteminin uygulandığı yıllara bakıldığında kurulan hükümetlere, şaşırtıcı şekilde başka ittifak ile seçime giren partilerin katıldığı; ittifak ile seçime giren partilerin hükümete desteklerini çektiği veya partilerin yasama dönemi içinde bölünerek yeni partilerin kurulduğu ve bunların hükümetten desteğini çektiği görülmüştür. Seçim ittifakını sınırlayan veya zorlaştıran hükümlerin yetersizliği ve partilerin sıklıkla ittifak değiştirmesi, seçim sisteminden beklenen amaca ulaşamamanın temel sebebi olarak görülebilir. Tablo 1'den görüleceği üzere bir ittifakın 340 milletvekiline sahip olduğu yasama dönemlerinde de kanunlaştırma oranlarında yeterli iyileşme görülmemektedir. Bunun sebebi hükümet ortağı olan partilerin desteklerini çekme tehdidinde bulunmuş olmalarıdır. Zira İtalya'da küçük partiler, özgül ağırlığının çok ötesinde bir güce ulaşmaktadırlar. ${ }^{60}$ Kanunlaştırma oranlarındaki düşüşe bir diğer sebep ise Temsilciler meclisindeki çoğunluğun, Senatoda çoğunluğa sahip olamamasıdır. Zikredildiği üzere çoğunluk ödüllü seçim sistemi Senato seçimlerinde farklı usuller ile uygulandığı için iki meclisteki çoğunluklar aynı olamamaktadır. Ancak 2008 yılı ile başlayan yasama yılında, her iki meclisin de aynı siyasi "ittifakın" elinde olması sayesinde kanunlaştırma oranlarının artması yukarıdaki yargıyı destekler niteliktedir. (Bkz. Tablo 1)

İtalya' da sorunları çözmek için yapılan çoğunluk ödüllü seçim sistemi merkez sağ ve merkez solda iki büyük siyasi ekolün "çatı" olmasına yol açmıştır. Ancak bu büyük partiler, Regalia'nın zikrettiği üzere barajın

60 PIATTONI, Simona, GIGLIOLI, Matteo Fabio Nels, Does Changing Electoral Systems Affect (Corrupt) Particularistic Exchanges? Evidence from the Italian Case, Politics and Governance, C. 7, S. 2, 2020, s. 80-82. 
düşük olması sonucu küçücük partilerin şantajlarının tutsağı haline gelmişlerdir. ${ }^{61}$

İtalya' da Senato'nun etkinliğinin bir Anayasa reformu ile azaltılmadan, siyasi istikrarı tek başına bir seçim reformu ile sağlamak mümkün olmadığı 2006, 2008 ve 2013 seçim sonuçları sonrası kurulan hükümetlerin ömrü ve icraatlarından anlaşılmaktadır. Seçim sisteminin ittifak kurulmasını oldukça destekleyen hükümleri, partilerin daha da bölünmesine yol açmakta ve çoğunluk ödüllü seçim sisteminin arzu edilen sonuçları vermemesini sağlamaktadır.

\section{B. Yunanistan}

Yunanistan, bağımsızlı̆̆ını ilan ettiği tarihten bu yana her daim çalkantılı bir siyasi atmosfere sahip olmuştur. Monarşi-cumhuriyet, komünizm-liberalizm gibi çekişmelere ilaveten sıklıkla yaşanan ekonomik buhranlar uzunca bir süre ülkeyi esiri altına almıştır. Ordunun bu kriz anlarını fırsata çevirerek sürekli darbe yaptığı veya darbeye teşebbüs ettiği görülmüştür. ${ }^{62}$ Yaşanan en son askeri darbe 1967 yılında gerçekleşmiş ve Türkiye'nin Kıbrıs Adasına askeri müdahalede bulunması ile askeri rejim 1974'te yıkılmıştır. ${ }^{63}$ Bugüne kadar kesintisiz bir şekilde sivil iktidarın görev yaptığı bu dönemde 2012 yılındaki kesinti hariç tutulursa güçlü iktidarların olduğu istikrarlı bir yönetim hayatı sürdürülmüştür.

Yunanistan'da çoğunluk ödüllü seçim sisteminin benimsenmesinden önce nispi temsil sistemi uygulanmasına rağmen iki partinin arasında seçim rekabetlerinin sürdüğ̈̈ ve hükümetin bu iki parti arasında birbirine devredildiği göze çarpmaktadır. 1980-2012 yılları üzerinden bir değerlendirme yapılacak olursa, çoğunluk seçim sistemine sahip İngiltere ve Malta'nın aksine Yunanistan'ın, nispi temsil seçim sistemine sahip olmasına rağmen saf iki partili sisteme sahip yegâne ülke olduğu

61 MARTA, Regalia, "Electoral Reform as an Engine of Party System Change", South European Society and Politics, C. 23, S. 1, 2018, s. 81-96.

62 “Sırasıyla 1831 (iki kez), 1843, 1862, 1909, 1916, 1922, 1925, 1926, 1935 ve 1967'te başarı ile sonuçlanan askeri darbeler; 1923, 1933, 1935, 1938, 1951, 1967, 1973, 1975 yıllarında ise başarısızlıkla sonuçlanan askeri darbe girişimleri yaşanmıştır." Bkz. TEKIN, Abdurrahman, Yunanistan, Ed. TEKİN, Abdurrahman, TEMEL, Ömer, CENGİ, İlyas Fırat, Osmanlı Ardıl Devletlerinin Siyasal Sistemleri, 2. Bs., Ankara, Adalet, 2020, s. 603; TRIDIMAS, George, "Political Economy Perspectives of the Fall of the Greek Monarchy", Democracy and an Open-Economy World Order, Ed. BITROS, George C., KYRIAZIS Nicholas C., Cham, Springer, 2017, s. 162.

63 HATZIS, Aristides N., “A Political History of Modern Greece, 1821-2018” Encyclopedia of Law and Economics, C. 39, S. 8, 2019, s. 844-851. 
görülecektir. ${ }^{64}$ Esasen sadece 1974 sonrası değil, II. Dünya Savaşı sonrasından beridir benzer tablo ile karşılaşılmaktadır. Yunanistan'da koalisyon hükümetleriyle oldukça kısa sayılabilecek birkaç dönemde, 19501952, 1963-1964 ve 1989-1990 yılları arasında karşılaşılmıştır. ${ }^{65}$ Duverger'in seçim sistemlerinin siyasi partiler üzerindeki etkileri üzerine yapmış olduğu sınıflandırmalarda çoğunluk sisteminin iki partili sistemi; buna karşın nispi temsil sisteminin ise çok partili sistemi doğuracağı zikredilmektedir. ${ }^{66} \mathrm{Bu}$ noktada, Duverger' in sinıflandırmasına uymayan nadir ülkelerden biri olarak Yunanistan'1 göstermek mümkündür.

Yunanistan'da yaşanan siyasi olayların siyasi bölünmelere, yeni partilerin ortaya çımasına ve seçmenlerin uzun süredir devam eden siyasi tercihlerinde değişikliğe gitmesine neden olması, seçim reformu tartışmalarını gün yüzüne çıkarmıştır. Yeni kurulan ve mevcut küçük muhalefet partilerinin giderek etkinleşmesi sonucu, siyasi iktidar, seçim sisteminde bir değişiklik yapılmasının zamanının geldiğini düşünerek çoğunluk ödüllü seçim sistemini hayata geçirmiştir. 2004 yılında kabul edilen bu seçim sisteminin ilk halinde birinci partiye ilave 40 milletvekilliği verilmekteydi. 260 sandalyenin paylaşımında ise nispi temsil sistemi uygulanmaktayd $1 .{ }^{67}$ Ancak Yunan Anayasasındaki hüküm nedeniyle söz konusu seçim reformu, meclis üye tamsayısının 2/3'ü ile kabul edilmediği için 2004 yılındaki seçimlerde uygulanmamış, 2007 seçimlerinde ilk kez uygulanmıştır. ${ }^{68} 2004$ yılında eski seçim sistemi ile 300 kişilik Mecliste New Democracy (ND) Partisi 165 milletvekiline sahip olurken; Panhellenic Socialist Movement (PASOK) 117 milletvekilinin sahibi olmuştur. Seçim sisteminin hayata geçtiği 2007 yılında ise ND 152 milletvekili, PASOK ise 102 milletvekilinin sahibi olmuştur. Benzer şekilde 2009 yılında 40 ödül milletvekilliğini alan PASOK 160, ND 91 milletvekilliği kazanmıştır. ${ }^{69} \mathrm{Bu}$

64 TSATSANIS, Emmanouil, TEPEROGLOU, Eftichia, Greece's coalition governments: Power sharing in a majoritarian democracy, Ed. EVANS, Matt, Coalition Government as a Reflection of a Nation's Politics and Society, New York, Routledge, 2019, s. 229.

65 TSATSANIS, TEPEROGLOU, s. 225-226

66 MAURICE, Duverger, Political Parties: Their Organization and Activity in the Modern State, Methuen, Wiley, 1954.

67 TSATSANIS/TEPEROGLOU, s. 227; Article 6 of Law 3231 / 2004 (GG 45 A).

68 Yunanistan Anayasası, 1974, m. 54.

69 HELLENIC PARLIAMENT, Election Results, 2021, hellenicparliament.gr/en/Vouliton-Ellinon/To-Politevma/Ekloges/Eklogika-apotelesmata-New/\#Per-11， (E. T. 15.01.2021). 
verilerden, çoğunluk ödüllü seçim sistemine geçme hususunda yukarıda yapılan çıkarımın doğruluğu gözükmektedir.

Tablo $2^{70}$

\begin{tabular}{|c|c|c|c|c|c|c|}
\hline & \multicolumn{2}{|c|}{$\begin{array}{c}\text { Partilerin Aldıkları } \\
\text { Oy Oranı }\end{array}$} & \multicolumn{2}{c|}{$\begin{array}{c}\text { Meclis'te Kazanılan } \\
\text { Sandalye Oranı }\end{array}$} & \multicolumn{2}{c|}{ Aşkın/Eksik Temsil } \\
\hline Partiler & $\mathbf{2 0 0 7}$ & 2009 & $\mathbf{2 0 0 7}$ & 2009 & $\mathbf{2 0 0 7}$ & 2009 \\
\hline ND & $\mathbf{\% 4 1 , 8}$ & $\% 33,5$ & $\mathbf{\% 5 0 , 6}$ & $\% 30,3$ & $\mathbf{+ \% 8 , 8}$ & $-\% 3,2$ \\
\hline PASOK & $\mathbf{\% 3 8 , 1}$ & $\% 43,9$ & $\mathbf{\% 3 4}$ & $\% 53,3$ & $\mathbf{- \% 4 , 2}$ & $+\% 9,4$ \\
\hline
\end{tabular}

2008 yılında seçim sisteminde bir reform yapma ihtiyacı hissedilmiştir. 2004 tarihli 3231 sayılı kanunda, 2008 tarihli 3636 sayılı kanun ile yapılan değişiklik ile artık 50 milletvekili birinci partiye verilecek, seçim barajı \%3 olacak $^{71}, 238$ milletvekili ülke çapında ayrılmış olan 56 seçim çevresinden çarşaf liste usulüne göre nispi temsil seçim sistemi ile, 12 milletvekili ise ülke çapında barajı geçmiş olan partilerin almış oldukları oy oranına göre seçilecekti. ${ }^{72}$ Ancak yapılan bu değişiklik, meclis üye tamsayısının 2/3'ü ile kabul edilmeyince 2009 yılında yapılan seçimlerde değil 2012 genel seçiminde uygulanmaya başlanmıştır. ${ }^{73}$ Bu reformun sebebi, partiler arası bölünmenin artması ve ödül olarak verilen milletvekili sayısının (40) bir sonraki seçimde hükümet kurmak için yetmeye(bile)cek olması şeklinde gösterilebilir. Nitekim 2012 yılında yapılan iki genel seçimde de partiler ve seçmenler arası bölünme o denli büyümüştür ki birinci parti ilave 50 milletvekilliğine rağmen tek başına hükümet kuracak sayıya ulaşamamıştır. ${ }^{74}$

7040 ödül milletvekilliği sisteminin uygulandığı 2007 ve 2009 seçimlerinde partilerin aldığı oy oranı, iki büyük partinin kazandığı milletvekili sayısı ve aşkın/eksik temsil oranlarını göstermektedir. Bkz. HELLENIC PARLIAMENT, Election Results, a.g.e..

71 Law 3231/2004 sayılı Kanun Law 3636/2008 ile değiştirilmiştir. (Law for the election of MPs), published on the Official Journal of the Government, ФEK 45/A/11.2.2004, art. 2, 3, 99 (3) http://www.dsanet.gr/Epikairothta/Nomothesia/n3231_04.htm, (E. T. 20.03.2021); KOKI, Constandina, LEONARDOS, Stefanos, Coalitions \& Voting Power in the Greek Parliament of 2012: A Case-Study, Homo Oeconomicus, C. 19, 2018, s. 4.

72 OSCE, Greece Early Parliamentary Elections 6 May 2012, 2012, osce.org/odihr/elections/92460, (E. T. 10.02.2021).

73 OSCE, Greece, s. 4

74 HELLENIC PARLIAMENT, Election Results, a.g.e.. 
Tablo $3^{75}$

\begin{tabular}{|c|c|c|c|c|c|c|c|c|c|}
\hline \multirow{3}{*}{ Partiler } & \multicolumn{3}{|c|}{ Partilerin Aldıkları Oy Oranı } & \multicolumn{3}{|c|}{$\begin{array}{c}\text { Meclis'te Kazanılan Sandalye } \\
\text { Oranı }\end{array}$} & \multicolumn{3}{|c|}{ Aşkın/Eksik Temsil } \\
\hline & 2012 & 2015 & 2019 & 2012 & 2015 & 2019 & 2012 & 2015 & 2019 \\
\hline & Haziran & Eylül & Haziran & Haziran & Eylül & Haziran & Haziran & Eylül & Haziran \\
\hline SYRIZA & $\% 26,9$ & $\% 35,5$ & $\% 31,5$ & $\% 23,6$ & $\% 48,3$ & $\% 28,7$ & $-\% 3,3$ & $+\% 12,8$ & $-\% 2,8$ \\
\hline ND & $\% 29,7$ & $\% 28,1$ & $\% 39,9$ & $\% 43$ & $\% 25$ & $\% 52,7$ & $+\% 13,3$ & $-\% 3,1$ & $+\% 12,8$ \\
\hline PASOK & $\% 12,3$ & $\% 6,3$ & $\% 8,1$ & $\% 11$ & $\% 5,6$ & $\% 7,3$ & $-\% 1,3$ & $-\% 0,7$ & $-\% 0,8$ \\
\hline XA & $\% 6,9$ & $\% 7$ & $\% 2,9$ & $\% 6$ & $\% 6$ & $\% 0$ & $-\% 0,9$ & $-\% 1$ & $-\% 2,9$ \\
\hline
\end{tabular}

2016 yılına gelindiğinde SYRIZA ve koalisyon ortakları, ülkesinin siyasi istikrarsızlıklarla boğuşacak olma ihtimalini yok sayarak seçim sistemini değiştirmiş, saf nispi temsil sistemini getirmiştir. Ancak söz konusu kanun değişikliği meclis üye tamsayısının 2/3'ü tarafından kabul edilmediği için 2019 genel seçimlerinde uygulanmamıştır. ${ }^{76}$ Çoğunluk ödüllü seçim sisteminin kalkmış olduğu Yunanistan'da bu seçim sistemi ile 2019 yılında son kez iktidarı kazanan ND Partisi, SYRIZA Partisinin kaldırdığı çoğunluk ödüllü seçim sistemini geri getirmek için seçim kanununu 2020 yılında tekrar değiştirmiştir. Normal şartlarda 2023 yılında yapılacak olan genel seçimlerde saf nispi temsil sistemi ile siyasi istikrarsızlıkların had safhaya ulaşacağı düşüncesi ile girişilen bu değişiklik, meclis üye tamsayısının 2/3'ü ile desteklenememiş ve ilerleyen ikinci seçimde hayata geçecek şekilde uykuya yatmıştır. Çoğunluk ödüllü seçim sisteminin özü olan ilave milletvekilliği hakkı bir şarta bağlanmış ve birinci partinin ödülü alabilmesi için en az \%25 oya ulaşması aranmıştır. Zira "Mayıs" 2012 yılında yapılan seçimlerde seçimi birinci bitiren ND, ödül olarak verilen 50 milletvekilliğini \%18,9 oy ile kazanmış ve Meclisin \%36'sına sahip olmuştur. ${ }^{77}$ Tekrar bu tür bir tablo ile karşılaşılmamak için bir alt sınır getirilmiştir. Buna ilaveten, verilecek ödül, alınan oy oranı ile artacak şekilde belirlenmiştir. Buna göre birinci olan parti 20 milletvekili ödülünü \%25'i geçme şartı ile elde edecektir. \%25'in üzerinde aldığı her

75 2012, 2015 ve 2019 yıllarındaki seçimlerde 50 bonus milletvekili uygulamasının sebebiyet verdiği aşkın/eksik temsil oranlarını göstermektedir. Bkz. HELLENIC PARLIAMENT, Election Results, a.g.e.; Carr, Adam, Greek Republic, psephos.adamcarr.net/countries/g/greece/, (E. T. 20.01.2021). Yunanistan'daki partiler: SYRIZA: Coalition of the Radical Left KKE:Communist Party of Greece; XA: Golden Dawn; DIMAR: Democratic Left.

76 LISI/TSATSANIS, s. 6.

77 HELLENIC PARLIAMENT, Election Results, a.g.e. 
$\% 0,5$ oy oranı ile bir ilave milletvekilliği ödülüne daha kavuşacaktır. Bu şekilde verilecek ödül sayısı 50 milletvekilini geçemeyecektir. ${ }^{78}$ Bir örnek ile somutlaştırmak gerekirse; seçimlerde $\% 35$ ile birinci olan parti $\% 25$ ten fazla oy alarak birinci olduğu için ilave 20 milletvekili ödül kazanacaktır. Buna ilaveten, \%25'ten fazla aldığ $\% 10$ oy için 20 ilave milletvekili kazanacak ve böylece 40 ödül milletvekilliğini elde edecektir. Aynı şekilde \%45 ile oy alan bir parti, 60 değil 50 ödül milletvekili kazanacaktır.

Yunanistan' da uygulanan çoğunluk ödüllü seçim sistemi için yap1lacak ilk çıkarım, sistemin, seçim sonuçlarında çoğunluğu garanti edememesidir. Sistemin benimsendiği 2004'ten bu yana yapılan 7 genel seçimin sadece üçünde, 2007, 2009 ve 2019, bir parti tek başına hükümet kuracak bir sayıya kavuşmuştur. (Bkz. Tablo 2-3) Elbette ki seçimlerde birinci çıkan partinin hükümeti kuracak seviyeye 4 seçimde ulaşamamış olmasına rağmen ödül milletvekillikleri ile güçlendirilerek hükümeti kurmalarının kolaylaştırıldığg 2010 'dan bu yana süregelen çalkantılı siyasi atmosferden en az zarar ile çıkabilmenin ancak böyle bir seçim sistemi ile mümkün olduğu söylenebilir.

Bu seçim sisteminin uygulanmasından çıkarılacak ikinci sonuç, seçim sisteminin, seçimlerin iki büyük parti etrafında dönmesini temin etmesidir. ${ }^{79}$ Zira seçim sonuçlarından, seçimlerin her daim iki büyük partinin çekişmesi ile sonuçlandığı görülebilmektedir. (Bkz. Tablo 2-3) Buna karşın etkili parti sayısında beklenenin aksine bir artış yaşanmıştır. ${ }^{80} \mathrm{Ma}-$ yıs 2012'de yapılan seçimlerde 7 siyasi partinin mecliste yer aldığ1 görülmektedir. Benzer şekilde Temmuz 2012'de 7; Temmuz 2015'te 7; Eylül 2015'te 8; 2019'da 6 siyasi parti meclise girmiştir. Buna karşın 2000 ve 2004 seçimlerinde sadece 4 parti meclise girebilmiştir. Seçime katılan siyasi parti sayılarında da benzer artışı görmek mümkündür. ${ }^{81}$ Esasen bu artışın sebebini sadece seçim sisteminde aramak doğru değildir. Zira İtalya'nın aksine Yunanistan'da seçim ittifakı mümkün değildir. Çoğunluk ödüllü seçim sistemi, seçim ittifakının olduğu ülkelerde seçime giren ve mecliste temsil edilen parti sayısını artırmaktadır. Yunanistan' da seçime katılan ve mecliste temsil olunan partilerin sayısındaki artışın asıl sebebini,

78 EKATHIMERINI, Parliament Votes to Change Election Law, 2020, ekathimerini.com/news/248820/parliament-votes-to-change-election-law/, (E. T. 09.03.2021).

79 Esasen bu seçim sisteminden önce de durum bu şekildeydi. Ancak bu seçim sistemi ile en azından durumun değişmemesi garanti edilmiş oldu.

80 GALLAGHER, s. 18-23. LISI/TSATSANIS, s. 12.

81 CARR, Greek Republic, a.g.e. 
Yunanistan'ın içinden geçmekte olduğu kriz ortamıdır. 1974'ten bu yana iktidarın el değiştirdiği ND ve PASOK partileri, 2009 yılında başlayan Küresel ekonomik krizin tetiklemesi ile ülkenin girdiği borç krizinin müsebbibi ilan edilmişlerdir. Ülkenin büyüme rakamlarının eksi hanelerden 2017 yılında çıktığında, ülke ekonomisinin son 10 yılda ortalama \%25 küçüldüğü görülmüştür. ${ }^{82}$ Ekonomik kriz, kamu borcu, işsizlik ve mülteci krizinin yaşandığı bu dönemde, yeni partilerin kurulması ve büyük partilerin parçalanarak küçülmesi kaçınılmaz olmuştur. Söz konusu seçim sisteminin olmadığı varsayımında meclisteki parçalanmışlık göz önüne getirildiğinde, çoğunluk ödüllü seçim sisteminin güçlü yürütmenin varlığını eksik de olsa temin ettiği daha iyi anlaşılacaktır.

Çoğunluk ödüllü seçim sisteminde, seçimlerden birinci çıkan partinin temsilde adil olmayacak şekilde ilave milletvekilliği kazandığı bir gerçek olsa da bu seçim sistemi Yunanistan'da şaşırtılanın aksine, daha önce uygulanmakta olan nispi temsil seçim sistemine göre seçim sonuçlarını temsilde adalete daha da yaklaştırmıştır. ${ }^{83} \mathrm{Bu}$ çıkarımı veriler ile desteklemek de mümkündür. Yunanistan'da barajsız ulusal listeli saf nispi temsil seçim sistemi ile alınan her \%1 oy ile 3 milletvekili kazanılmaktadır. Örneğin, çoğunluk ödüllü seçim sisteminin uygulandığı Mayıs 2012 seçiminde \%6,1 oy alan DIMAR 19 milletvekili kazanırken; XA \%7 oy ile 21 milletvekili kazanmıştır. Benzer şekilde Temmuz 2015 seçimlerinde XA Partisi \%6,3 ile 17 PASOK \%4,7 ile 13 milletvekili elde etmiştir. Buna karşın 2004 yılında eskiden uygulanan nispi temsil seçim sisteminde KKE $\% 5,9$ oy ile 12 milletvekili; \%3,3 oy alan SYRIZA ise 6 milletvekili kazanmıştır. ${ }^{84}$

\section{San Marino}

Tek parti iktidarının en son 1949'ta görüldüğü San Marino' da ittifak halinde meclis çoğunluğu ise en son 1951'de kazanılmıştır. 2000'li yıllara kadar genel olarak 6 parti Mecliste temsil edilmiş ancak 2006 yılında Meclise 9 partinin girmesi Mecliste karar alımını ciddi manada etkilemiş ve yönetimde istikrarda sarsıntılara yol açmıştır. 2008 yılında hükümetin dağılmasından önce öngörülü bir şekilde yapılan seçim kanunu değişikliği ile çoğunluk ödüllü seçim sistemi benimsenmiştir. Alınan erken seçim

\footnotetext{
82 Yunanistan'ın yaşadığ krizler ve etkileri ile siyasi partilerin geçmişten günümüze, bilhassa bu süreç içerisindeki evrimi hakkında Bkz. TEKİN, 2020, s. 624-630.

83 PATRIKIOS/KARYOTIS, 2008, s. 357.

84 HELLENIC PARLIAMENT, Election Results, a.g.e..
} 
kararı ile 2008 yılında seçimler yenilenmiştir. Seçim kanununun, seçim ittifaklarına izin vermesi ile iki büyük ittifakın etkinlik gösterdiği seçim sonuçlarından anlaşılmaktadır. Her ne kadar son iki genel seçimde 2,5 büyük ittifakın varlığı göze çarpsa da genel manada küçük partileri büyük partiler ile ittifaka zorlayan bir sistemin varlığı göze çarpmaktadır. ${ }^{85} \mathrm{Bu}$ noktada, çoğunluk ödüllü seçim sisteminden beklenilen sonucun San Marino'da alındığı söylenebilir.

Kabul edilen seçim sistemine göre ülke barajı $0.4^{\prime}$ ten \%3,5'a yükseltilmiştir. Ödül olarak ise 60 kişiden oluşan meclisin 35 milletvekili seçimi kazanan partiye/ittifaka verilmektedir. Partinin/ittifakın söz konusu ödülü kazanması için tek şart \%50' den fazla oy almasıdır. ${ }^{86}$ Nitekim 2008 ve 2012 yıllarında yapılan genel seçimlerde bu oran geçilerek 35 milletvekilinin sahibi olunmuştur. Hiçbir partinin \%50'den fazla oy alamaması durumunda ise söz konusu ödül, en çok oyu almış iki büyük parti/ittifakın ikinci turda tekrar yarışması sonucu kazanana verilmektedir. ${ }^{87} 2016$ y1lında gerçekleşen bu hadise sonucu seçimin ilk turunu 20 milletvekili kazanarak ikinci sırada bitiren "Adesso.sm" ittifakı ikinci turdaki seçimde \%58'e yakın oy ile galip gelerek 35 milletvekilinin sahibi olmuştur. ${ }^{88} \mathrm{Bu}$ seçim sistemi için bir nevi, kazananı kaybedenlerin ikinci tercihlerinin belirlediği bir seçim sistemi olarak tanımlamak da mümkündür. İlk turda $\% 31,43$ oy alan ittifakın ikinci turda gelen zaferi ile meclisin \%58,3'üne sahip olması temsilde adalet açısından eleştiriye açık bir konudur. Yönetimde istikrar için bu denli bir dengesizliği kabul etmek ne kadar doğrudur sorusu akla gelmektedir.

2019 yılında seçim kanununda yapılan bir değişiklik ile hiçbir partinin \%50'ye ulaşamaması durumunda zorunlu olan ikinci tur seçimi uygulaması ihtiyarileştirilmiştir. Şöyle ki seçimin ilk turundan sonra en çok

85 CARR, Most Serene Republic of San Marino, a.g.e.

86 OSCE, Republic of San Marino Early Parliamentary Elections, 2016, s. 4, osce.org/files/f/documents/f/3/280341.pdf, (E. T. 25.02.2021).

87 SEGRETERIA DI STATO PER GLI AFFARI ESTERI SAN MARINO, Risultato generale elezioni del 11/11/2012, elezioni.sm/on-line/home/elezioni-politiche/elezionidel-11112012.html, (E. T. 21.02.2021); SEGRETERIA DI STATO PER GLI AFFARI ESTERI SAN MARINO, Risultato generale elezioni 9/11/2008, elezioni.sm/online/home/elezioni-politiche/elezioni-del-09112008.html, (E. T. 21.02.2021).

88 SEGRETERIA DI STATO PER GLI AFFARI ESTERI SAN MARINO, BALLOTTAGGIO- 4 Dic. 2016- Risultato Generale, elezioni.sm/on-line/home/elezioni-politiche/elezioni-del-20112016/risultati-ballotaggio-4-dic-2016/generale.html, (E. T. 21.02.2021). 
oyu almış iki parti/ittifaka 15'er gün süre tanımlanarak hükümeti kurmaları istenmektedir. 30 günün sonunda herhangi bir ittifakın hükümeti kuramaması durumunda seçimde en çok oy almış bu iki parti/ittifakın ikinci turda tekrar yarışması sağlanmaktadır. İkinci turda kazanan parti/ittifaka 35 milletvekili verilmekte ve kalan 25 milletvekili birinci turda alınan oylar nispetinde diğer partilere dağıtılmaktadır. ${ }^{89} 2019$ yılında yapılan seçimler sonucu hiçbir parti \%50'den fazla oy alamamış ancak koalisyon görüşmeleri sonucu çıan uzlaşma sonucu hükümet kurulabilmiştir. Böylece seçimler ikinci tura kalmamış ve temsilde adaletsizlikler ile sonuçlanmayan bir tablo ortaya çıkmıştır. ${ }^{00}$

\section{SONUÇ}

Seçmenlerin vermiş olduğu oylar ile birincilikle ödüllendirilen partinin veya seçim ittifakının, bir de seçim sistemi tarafından ödüllendirildiği sisteme çoğunluk ödüllü seçim sistemi demekteyiz. Bu seçim sisteminin birinci yönteminde, birinci olan parti/ittifaka daha önceden belirlenen bir sayıda ilave milletvekilliği verilmektedir. Yunanistan'da görülen bu yöntemde, ilave milletvekilliği ile güçlü bir parti hedeflenmekte, hükümetin kolay kurulması sağlanmakta ancak her zaman partinin meclis çoğunluğuna ulaşması mümkün olamamaktadır. İkinci yöntem ise İtalya' da uygulanmış ve San Marino' da uygulanmakta olup birinci partiye/ittifaka meclis üye tamsayısının \%54-58'i bahşedilerek parti/ittifakın meclis çoğunluğunu garanti etmesi sağlanmaktadır.

Çoğunluk ödüllü seçim sistemini benimseyen ülkelerde görülen ortak husus, seçim sistemi üzerinde sürekli tartışmaların ve değişikliklerin yaşanmasıdır. Hatta İtalya'da 2 kez Anayasa Mahkemesi devreye girerek seçim sisteminin bazı hükümlerini iptal yoluna gitmiştir.

Çoğunluk ödüllü seçim sistemi temsilde adaletsiz bir şekilde bir partiye ödül vermekte ancak küçük partiler de sistemden koparılmamaktadır. Birinci olamayan partilere milletvekilliklerin dağıtımının, genellikle nispi temsil ile olması, barajın oldukça düşük belirlenmesi ve genel olarak seçim ittifaklarına imkân verilmesi bu seçim sistemini benimseyen ülkelerde görülen ortak özelliklerdir. Bu özellikler sayesinde küçük partiler

89 SEGRETERIA DI STATO PER GLI AFFARI ESTERI SAN MARINO, Sistema Elettorale Vigente Nella Repubblica di San Marino, elezioni.sm/on-line/home/elezioni-politiche/sistema-elettorale.html, (E. T. 20.02.2021).

90 SEGRETERIA DI STATO PER GLI AFFARI ESTERI SAN MARINO, Risultati Generale 2019, elezioni.sm/on-line/home/elezioni-politiche/elezioni-del-08122019/risultati/articolo26013816.html, (E. T. 21.02.2021). 
de etken bir pozisyona taşınmaktadır. Seçim sonuçları incelendiğinde seçim yarışına ve meclise giren parti sayısında ciddi bir artış gözlemlenmiştir. Bu durum seçim ittifakı ile birlikte değerlendirildiği zaman, ittifak içerisindeki büyük partiler, küçük partilerin çeşitli konularda tutsağı haline gelebilmektedir çıkarımı yapılmaktadır.

Çeşitli sonuçların çıkarılabileceği bu seçim sistemi, parçalı meclis figürünün olduğu ve uzlaşma kültürünün siyasette kanıksanmadığı toplumlarda sıklıkla görülen yönetimde istikrarsızlı̆̆ı ortadan kaldırmak için uygun bir seçim sistemi olarak göze çarpmaktadır. Ancak çoğunluk ödüllü seçim sisteminin, seçim çevresi, baraj, ittifak, tercihli oy gibi etmenler ile bütünleştiği zaman temsilde adaletsizliği minimuma indirecek şekilde kurgulanması daha uygun olacaktır. 


\section{KAYNAKLAR}

AA, "Hollanda'da 200 gündür hükümet kurulamadi", https://www.aa.com.tr/tr/dunya/hollandada-200-gundur-hukumet-kurulamadi/924214, (E. T. 17/03/2021).

AGNEW, John “Remaking Italy? Place Configurations and Italian Electoral Politics under the Second Republic", Modern Italy, C. 12, S. 1, 2007.

BALDINI, Gianfranco, “The Different Trajectories of Italian Electoral Reforms", West European Politics, C. 34, S. 3, 2011.

RASGON, Adam, Israel Has Its 4th National Election in 2 Years. Here's Why, https://www.nytimes.com/2021/03/17/world/middleeast/israeli-election.html, (E. T. 17/03/2021).

BEDOCK, Camille, SAUGER, Nicolas, Electoral Systems with Majority Bonus as Unconventional Mixed Systems, Representation, 2014, C. 50, S. 1 , s. $99-112$

BEDOCK, Camille, SAUGER, Nicolas, Electoral Systems with Majority Bonus as Mixed Systems Congrès AFSP, 2013.

Carr, Adam, Greek Republic, psephos.adam-carr.net/countries/g/greece/, (E. T. 20.01.2021).

CARR, Adam, Most Serene Republic of San Marino, 2021, psephos.adamcarr.net/countries/s/sanmarino/, (E. T. 10.03.2021).

CHIARAMONTE Alessandro, D'ALIMONTE, Roberto, The New Italian Electoral System and its Effects on Strategic Coordination and Disproportionality, Italian Political Science, C. 13, S. 1, 2018.

CHIARAMONTE, Alessandro, The Unfinished Story of the Electoral Reforms in Italy: The Difficult Attempt to Build a Majoritarian-Style of Government, 2014, http://www.sisp.it/files/papers/2014/alessandro-chiaramonte-1827.pdf, (E. T. 11.03.2021).

COURTE CONSTITUZIONALE, 2014, https://dochero.tips/judgment-no1-year-2014.html, (E. T. 21.02.2021).

D'ALIMONTE, Roberto, The New Italian Electoral System: Majority-Assuring But Minority-Friendly, Contemporary Italian Politics, C.7, S. 3, s. 286-292.

DIAN, Schefold, Constitutional Reform and Constitutional Unity, The Italian Law Journal, Special Issue, 2017. 
DIPARTIMENTO PER GLI AFFARI INTERNI E TERRITORIALI, 2021, https://elezionistorico.interno.gov.it/index.php, (E. T. 18.03.2021).

DIPARTIMENTO PER GLI AFFARI INTERNI E TERRITORIALI, Camera 07/06/1953 Area Italia, 2021, elezionistorico.interno.gov.it/index.php?tpel=C\&dtel=07/06/1953\&tpa=I\&tpe=A\&lev0=0\&levsut0=0\&es0=S\&ms=S, (E. T. 19.01.2021).

DIPARTIMENTO PER GLI AFFARI INTERNI E TERRITORIALI, Camera 09/04/2006 Area Italia (escl. Valle d'Aosta), elezionistorico.interno.gov.it/index.php?tpel=C\&dtel=09/04/2006\&tpa=I\&tpe=A\&lev0=0\&levsut $0=0 \&$ es $0=S \& m s=S$, (E. T. 23.02.2021).

DIPARTIMENTO PER GLI AFFARI INTERNI E TERRITORIALI, Camera 13/04/2008 Area Italia (escl. Valle d'Aosta), 2021, elezionistorico.interno.gov.it/in-

dex.php?tpel=C\&dtel=13/04/2008\&tpa=I\&tpe=A\&lev0=0\&levsut $0=0 \&$ es $0=S \& m s=S$, (E. T. 20.02.2021).

DIPARTIMENTO PER GLI AFFARI INTERNI E TERRITORIALI, Camera 18/04/1948 Area Italia, (çevrimiçi) http://elezionistorico.interno.it/index.php?tpel=C\&dtel=18/04/1948\&tpa=I\&tpe=A\&lev0=0\&levsut $0=0 \&$ es $0=S \& m s=S$, (E. T. 11.02.2021).

DIPARTIMENTO PER GLI AFFARI INTERNI E TERRITORIALI, Camera 24/02/2013 Area Italia, elezionistorico.interno.gov.it/index.php?tpel=C\&dtel=24/02/2013\&tpa=I\&tpe=A\&lev0=0\&levsut0=0\&es0=S\&ms=S, (E. T. 12.01.2021).

DIPARTIMENTO PER GLI AFFARI INTERNI E TERRITORIALI, Camera 24/02/2013 Area Italia, 2021, elezionistorico.interno.gov.it/index.php?tpel=C\&dtel=24/02/2013\&tpa=I\&tpe=A\&lev0=0\&levsut $0=0 \&$ es $0=S \& m s=S$, (E. T. 18.01.2021).

Disposizioni in Materia di Elezione Della Camera Dei Deputati, Legeg 6 Maggio 2015.

EKATHIMERINI, Parliament Votes to Change Election Law, 2020, ekathimerini.com/news/248820/parliament-votes-to-change-election-law/, (E. T. 09.03.2021). 
EUROPEAN COMMISSION FOR DEMOCRACY THROUGH LAW (VENICE COMMISSION), Report on Electoral Law and Electoral Administration in Europe, 2020.

FUSARO, Carlo, "Party System Developments and Electoral Legislation in Italy (1948-2009)", Bulletin of Italian Politics, C. 1, S. 1, 2009.

GALLAGHER, Michael, 2017, “Election Indices Dataset", https://www.tcd.ie/Political_Science/people/michael_gallagher/ElSystems/Docts/ElectionIndices.pdf, (E. T. 10.03.2021).

GOLDONI, Marco, Italian Constitutional Referendum: Voting for Structural Reform or Constitutional Transformation?, Verfassungsblogon Matters Constitutional, verfassungsblog.de/italian-constitutional-referendum-voting-goldoni/, (E. T. 02.02.2021).

GOVERNO ITALIANO PRESIDENZA DEL CONSIGLIO DEI MINISTRI, Governo Berlusconi IV, governo.it/it/i-governi-dal-1943-adoggi/xvi-legislatura-dal-29-aprile-2008-al-23-dicembre-2012/governo-berlusconi, (E. T. 10.01.2021).

HATZIS, Aristides N., “A Political History of Modern Greece, 1821-2018” Encyclopedia of Law and Economics, C. 39, S. 8, 2019.

HELLENIC PARLIAMENT, Election Results, 2021, hellenicparliament.gr/en/Vouli-ton-Ellinon/To-Politevma/Ekloges/Eklogikaapotelesmata-New/\#Per-11, (E. T. 15.01.2021).

HORCASITAS, Juan Molinar, WELDON, Jeffrey A., Reforming Electora 1 Systems in Mexico, Ed. SHUGART, Matthew Soberg, WATTENBERG, Martin P., Mixed-Member Electoral Systems The Best of Both Worlds?, Oxford, Oxford University Press, 2001.

KOKI, Constandina, LEONARDOS, Stefanos, Coalitions \& Voting Power in the Greek Parliament of 2012: A Case-Study, Homo Oeconomicus, C. 19, 2018.

Law 3231/2004 sayılı Kanun Law 3636/2008 ile değiştirilmiştir. (Law for the election of MPs), published on the Official Journal of the Government, ФEK 45/A/11.2.2004, art. 2, 3, 99 (3) http://www.dsanet.gr/Epikairothta/Nomothesia/n3231_04.htm,

(E. T. 20.03.2021).

Law 3636/2008 (Law for the election of MPs), published on the Official Journal of the Government, ФEK 45/A/11.2.2004, http://www.dsanet.gr/Epikairothta/Nomothesia/n3231_04.htm, (E. T. 20.03.2021). 
LISI, Marco, TSATSANIS, Emmanouil, Southern Europe and the eurozone crisis: political representation, party system characteristics and the impact of austerity, Ed. FREIRE, André, BARRAGAN, Mélany, COLLER, Xavier, LISI, Marco, RIVAS, Cristina, TSATSANIS, Emmanouil, Political representation in Southern Europe and Latin America: Crisis or Continuing Transformation?, New York, Routledge, 2020.

MARTA, Regalia, "Electoral Reform as an Engine of Party System Change", South European Society and Politics, C. 23, S. 1, 2018.

MAURICE, Duverger, Political Parties: Their Organization and Activity in the Modern State, Methuen, Wiley, 1954.

MINISTERE DE L'INTERIEUR, Résultats des élections législatives 2017, interieur.gouv.fr/Elections/Les-resultats/Legislatives/elecresult_legislatives-2017/(path)/legislatives-2017//FE.html, (E. T. 15.01.2021).

MITCHELL, Paul, The United Kingdom: Plurality Rule Under Siege, The Politics of Electoral Systems, Ed. by. GALLAGHER, Michael, MITCHELL, Paul, New York, Oxford University Press, 2005.

MORGAN, Philip, Italian Facism 1915-1945, 2. bs., New York, Palgrave Macmillan, 2004.

ORTONA, Guido, OTTONE, Stefania, PONZANO, Ferruccio, “A Simulative Assessment of The Italian Electoral System", Department of Public Policy and Public Choice - POLIS, 2005.

OSCE, Greece Early Parliamentary Elections 6 May 2012, 2012, osce.org/odihr/elections/92460, (E. T. 10.02.2021).

OSCE, Republic of San Marino Early Parliamentary Elections, 2016, osce.org/files/f/documents/f/3/280341.pdf, (E. T. 25.02.2021).

PASSARELLI, Gianluca, Electoral Systems in Context: Italy, Ed. HERRON, Erik S. PEKKANEN, Robert J., SHUGART, Matthew S., The Oxford Handbook of Electoral Systems, New York, Oxford University Press, 2018.

PATRIKIOS, Stratos, KARYOTIS, Georgios, “The Greek Parliamentary Election of 2007", Electoral Studies, V. 27/2, 2008, s. 356-359.

PIATTONI, Simona, GIGLIOLI, Matteo Fabio Nels, Does Changing Electoral Systems Affect (Corrupt) Particularistic Exchanges? 
1810 | Dr. Öğr. Üyesi Abdurrahman TEKİN

Evidence from the Italian Case, Politics and Governance, C. 7, S. 2, 2020.

POLITCAL DATABASE OF AMERICAS, United Mexican States Election Results, https:/Politi/pdba.georgetown.edu/Elecdata/Mexico/mexico.html, (E. T. 20.02.2021).

RENWICK Alan, The Politics of Electoral Reform: Changing the Rules of Democracy, Cambridge: Cambridge University Press, 2010.

REYNOLDS, Andrew, REILLY, Ben, The International IDEA Handbook of Electoral System Design, SRM Production Services, Malaysia, 2002.

SEGRETERIA DI STATO PER GLI AFFARI ESTERI SAN MARINO, BALLOTTAGGIO- 4 Dic. 2016- Risultato Generale, elezioni.sm/on-line/home/elezioni-politiche/elezioni-del20112016/risultati-ballotaggio-4-dic-2016/generale.html, (E. T. 21.02.2021).

SEGRETERIA DI STATO PER GLI AFFARI ESTERI SAN MARINO, Risultati Generale 2019, elezioni.sm/on-line/home/elezioni-politiche/elezioni-del-08122019/risultati/articolo26013816.html, (E. T. 21.02.2021).

SEGRETERIA DI STATO PER GLI AFFARI ESTERI SAN MARINO, Risultato generale elezioni del 11/11/2012, elezioni.sm/online/home/elezioni-politiche/elezioni-del-11112012.html, (E. T. 21.02.2021).

SEGRETERIA DI STATO PER GLI AFFARI ESTERI SAN MARINO, Risultato generale elezioni 9/11/2008, elezioni.sm/online/home/elezioni-politiche/elezioni-del-09112008.html, (E. T. 21.02.2021).

SEGRETERIA DI STATO PER GLI AFFARI ESTERI SAN MARINO, Sistema Elettorale Vigente Nella Repubblica di San Marino, elezioni.sm/on-line/home/elezioni-politiche/sistema-elettorale.html, (E. T. 20.02.2021).

SOLAK, Mehmet, “İstikrarsız Hükümetler ve Sürekli Reform Arayışı: İtalya'da Parlamenter Sistem", Ed. YAPICI KAYA, Havvana, TBMM Araştırma Merkezi Yayınları Karşılaştırmalı Hükümet Sistemleri: Parlamenter Sistem (Almanya, Güney Afrika, Hindistan, İngiltere, İtalya ve Japonya Örnekleri), TBMM Basımevi, Ankara, 2015. 
STRATFOR, How Electoral Reform Effect Italian Politics, 6 May 2015, https://worldview.stratfor.com/article/how-electoral-reformwill-affect-italian-politics, (E. T. 15.03.2021).

TBMM, Hükümetler Listesi, 2021, tbmm.gov.tr/kutuphane/e_kaynaklar_kutuphane_hukumetler.html, (E. T. 10.01.2021).

TEKINN, Abdurrahman, Yunanistan, Ed. TEKİN, Abdurrahman, TEMEL, Ömer, CENGİZ, İlyas Fırat, Osmanlı Ardıl Devletlerinin Siyasal Sistemleri, 2. Bs., Ankara, Adalet, 2020.

TRIDIMAS, George, "Political Economy Perspectives of the Fall of the Greek Monarchy", Democracy and an Open-Economy World Order, Ed. BITROS, George C., KYRIAZIS Nicholas C., Cham, Springer, 2017.

TSATSANIS, Emmanouil, TEPEROGLOU, Eftichia, Greece's coalition governments: Power sharing in a majoritarian democracy, Ed. EVANS, Matt, Coalition Government as a Reflection of a Nation's Politics and Society, New York, Routledge, 2019.

UK PARLIAMENT, General Election 2019: Full Results and Analysis, commonslibrary.parliament.uk/research-briefings/cbp-8749/, (E. T. 15.01.2021).

WILLS, Mark, Et Tu, Brute? Is the Italian Referendum the Second Act of the European Union's Tragedy?, 2016, s. 2, https://www.ssga.com/publications/investment-quarterly/2016/et-tu-brute-is-the-italian-referendum-04102016.pdf, (E. T. 11.03.2021). 